\title{
Multimodaalisuus 1. ja 4. Iuokan suomalaisissa matematiikan oppikirjoissa
}

\section{Daranee Lehtonen}

Helsingin yliopisto, humanistinen tiedekunta; Tampereen yliopisto, kasvatustieteiden tiedekunta

Tässä tutkimuksessa tarkasteltiin 1. ja 4. luokan matematiikan oppikirjojen multimodaalista tekstiympäristöä eli moninaisten semioottisten resurssien käyttöä, joka on keskeistä matematiikan oppimisessa. Tavoitteena oli selvittää, 1) millaisia semioottisia resursseja oppikirjoissa on sekä luettavaksi annettuna (ts. tekstien tulkinnassa) että tehtäviksi annettuna (ts. tehtävien tekstien tuottamisessa), 2) miten niitä hyödynnetään merkitysten luomisessa ja 3) kuinka monipuolisesti semioottisia resursseja hyödynnetään oppikirjoissa. Tutkimuksen lähestymistapana on monimenetelmä (mixed-methods). Aluksi tarkastelin aineistojen diskurssia yleisellä tasolla soveltaen metafunktiota ja aikaisempia tutkimuksia. Sen jälkeen erittelin aineiston sisältöjä määrällisesti: onko kyseessä tekstien tulkinta vai tuottaminen ja mitä semioottisia resursseja käytetään. Lopuksi tarkastelin eriteltyjen aineistojen diskurssia. Tutkimustulokset osoittavat, että multimodaalisuuden näkökulmasta monipuolisia tekstiympäristöjä huomioidaan hyvin vähän tutkituissa oppikirjoissa. Matematiikan symbolikieli on selkeästi dominoiva erityisesti tekstien tuottamisessa. Kaikissa oppikirjoissa erilaisia semioottisia resursseja hyödynnetään enimmäkseen vain oppilaan luku- ja laskutaitojen perusteella sekä matematiikan opetettavien sisältöalueiden kannalta. Oppilaan monilukutaidon kannalta matematiikan oppikirjojen tekstiympäristö voisi olla monipuolisempi: oppilaalle voitaisiin tarjota enemmän multimodaalista luettavaa ja tuotettavaa.

\section{Artikkelin tiedot}

LUMAT General Issue Vol 6 No 1 (2018), 129-164

Lähetetty 3.5.2018

Hyväksytty 9.11 .2018

Julkaistu 21.12.2018

Sivuja: 36

Lähteitä: 28

Yhteystiedot: daranee.lehtonen@tuni.fi

https://doi.org/10.31129/ LUMAT.6.1.341

Avainsanat: multimodaalisuus, matematiikka, oppikirja, alakoulu

\section{Multimodality in $1^{\text {st }}$ - and $4^{\text {th }}$-grade Finnish mathematics textbooks}

This study investigated first- and fourth-grade mathematics textbooks' multimodal text environment. It aimed to discover 1) what semiotic resources are utilised for interpreting and producing texts, 2) how they are used for meaning-making and 3) how diversely. The inquiry strategy was mixed-methods. First, I analysed discourse of the research data generally using metafunction and previous research. Then, I quantified each semiotic resource's distribution in terms of text interpretation and production and types of semiotic resources. Finally, I analysed discourse of each quantified data. Research findings demonstrate that from a multimodal perspective, diverse textual environment is barely paid attention to. The symbolic language is dominant, especially to text production. In all textbooks, semiotic resources are used mainly on the basis of student's literacy and numeracy and tobe-leant mathematics contents. In favour of a student's multiliteracies, mathematics textbooks' text environment should be more diverse: offer more multimodal text interpretation and production.

Keywords: multimodality, mathematics, textbook, lower elementary school 


\section{Johdanto}

Matemaattinen diskurssi voidaan nähdä multimodaalisena toisin sanoen moninaisten semioottisten resurssien viestintänä. Matemaattinen teksti rakentuu usein kolmesta semioottisesta resurssista: matematiikan symbolikielestä, luonnollisesta kielestä ja kuviokielestä, jotka nivoutuvat yhteen kokonaisuudeksi (mm. Joutsenlahti \& Kulju, 2010; Lemke, 2003; O’Halloran, 2005; Schleppegrell, 2010). Multisemioottinen viestintä tukee muun muassa oppilaan matemaattista ajattelua ja käsitteiden ymmärtämistä (Joutsenlahti \& Kulju, 2010; Morgan, 2001; O’Halloran, 2015a). Täten multimodaalisuudella on merkittävä rooli matematiikan oppimisessa.

Vuoden 2014 perusopetuksen opetussuunnitelman perusteissa (Opetushallitus, 2015) esitetään, että multimodaaliseksi muuttuvassa tekstimaailmassa oppilaan tulee kehittää omaa monilukutaitoaan (multiliteracies). Opetussuunnitelman mukaan "monilukutaito perustuu laaja-alaiseen käsitykseen tekstistä", joka voi olla "sanallisten, kuvallisten, auditiivisten, numeeristen ja kinesteettisten symbolijärjestelmien sekä näiden yhdistelmien avulla ilmaistua tietoa” (s. 22). Opetussuunnitelma korostaa, että monilukutaitoa (ts. erilaisten tekstien tulkitsemisen, tuottamisen ja arvottamisen osaamista) kehitetään kaikissa oppiaineissa kaikilla luokka-asteilla. Oppilaiden monilukutaidon kehittyminen edellyttää monipuolisia tekstiympäristöjä, joista yksi onkin monimuotoisia tekstejä hyödyntävä oppimateriaali (Opetushallitus, 2015, ss. 22-23). Matematiikan opetuksen osalta multimodaalisuus on eräs keskeinen tavoite, sillä perusopetuksessa oppilaita rohkaistaan ilmaisemaan matemaattista ajatteluaan, päätelmiään ja ratkaisujaan eri tavoin ( $\mathrm{mm}$. kirjallisesti, suullisesti ja piirtäen) ja välineillä (ss. 128, 235, 374).

Monissa maissa Suomi mukaan lukien matematiikan opetus on oppikirjapainotteista (esim. Alshwaikh \& Morgan, 2013; van den Heuvel-Panhuizen \& Wijers, 2005; Jellis, 2008; Johansson, 2006; Joutsenlahti \& Vainionpää, 2010). Joutsenlahden ja Vainionpään (2010) tutkimuksessa suurin osa suomalaisista luokanopettajista pitää oppikirjaa välttämättömänä matematiikan opetuksessa. Lisäksi Niemen (2008) tutkimustulokset osoittavat, että opetuksessa käytetyllä oppikirjalla on yhteys alakoulun oppilaiden suorituksiin. Edellä esitettyjen perusteella voidaan sanoa, että oppikirjoilla on keskeinen asema matematiikan opetuksessa. Näin oppikirjoilla on väistämättä suuri vaikutus oppilaiden 
multimodaalisen viestintätaidon kehittymiseen sekä matematiikan oppimiseen. Matematiikan oppikirjojen multimodaalisuuden tutkimus palvelee oppikirjojen kehittämistä ja käyttämistä. Kiinnostus oppikirjojen multimodaalisuuden tutkimukseen onkin herännyt vuosituhannen vaihteessa, mutta Suomessa sitä on tutkittu melko vähän. Matematiikan oppikirjojen osalta on julkaistu muutamia tutkimuksia. Kautto ja Peltoniemi (2006) tutkivat 4. luokan oppikirjojen kuvituksen muutosta (kuvien lukumäärän, kuvatyypin ja tehtävien muutosta) vuosina 19702004 kuva-analyysin avulla. Joutsenlahti ja Kulju (2010) tarkastelivat luonnollista kieltä ja symbolikieltä sanallisissa tehtävissä kielitieteen näkökulmasta. Ollikainen ja Rossin (2007) tutkivat sisällönanalyysillä, miten eri 3. luokan oppikirjojat tukevat oppilaan matemaattista ajattelua hyödyntämällä multisemioottisia resursseja. Kuitenkaan aiemmissa kotimaisissa tutkimuksissa ei ole tarkasteltu oppikirjojen multimodaalista tekstiympäristöä kokonaisuutena.

Tämän tutkimuksen tavoitteena olikin selvittää eri alakoulun matematiikan oppikirjasarjojen multimodaalista tekstiympäristöä eli multisemioottista viestintää. Lisäksi tutkimustuloksia peilataan uudessa opetussuunnitelmassa (Opetushallitus, 2015) mainittuun monilukutaidon oppimisen tavoitteeseen. Tutkimuksessa pyrin vastaamaan seuraaviin kysymyksiin: 1) millaisia semioottisia resursseja oppikirjoissa on sekä luettavaksi annettuna (ts. tekstien tulkinnassa) että tehtäviksi annettuna (ts. tehtävien tuottamisessa), 2) miten niitä hyödynnetään merkitysten luomisessa ja 3) kuinka monipuolisesti semioottisia resursseja hyödynnetään oppikirjoissa?

Tutkimus jakautuu kuuteen lukuun: 1) tutkimuslähtökohdat, tutkittava ilmiö sekä tutkimustavoitteet ja -kysymykset, 2) multimodaalisuuden teoriatausta ja multimodaalisuus matematiikassa, 3) tutkimusaineistot ja -metodit, 4) tulokset, 5) pohdinta ja 6) johtopäätökset.

\section{Multimodaalisuus}

Ensin tarkastelen yleisempää multimodaalisuuden teoriataustaa sekä siihen liittyviä käsitteitä ja teoreettisia viitekehyksiä. Sen jälkeen keskityn multimodaalisuuteen matematiikassa. 


\subsection{Multimodaalisuuden teoriatausta}

Jewittin, Bezemerin ja O'Halloranin (2016) multimodaalisuuden määritelmä viittaa siihen, että ihmiset kommunikoivat käyttämällä erilaisia resursseja (esim. puhetta, katsetta ja eleitä) merkityksen rakentamiseen (meaning-making). Heidän mukaansa multimodaalisesta näkökulmasta verbaalista viestintää ei pidetä muita tärkeämpänä, vaan merkityksiä rakennetaan erilaisten semioottisten resurssien kokonaisuudella. Merkityksen rakentamisessa semioottiset resurssit tarjoavat erilaisia mahdollisuuksia ja samalla ne ovat sidoksissa toistensa kanssa, joten multimodaalisuuden tutkimuksessa pyritään tarkastelemaan kaikkia käytettyjä semioottisia resursseja (Jewitt ym., 2016).

Multimodaalisuutta on tutkittu eri tiedonaloilla. Eri tiedonaloilla on eri tutkimusfokuksia, mitkä näkyvät niiden hyödyntämissä teorioissa ja menetelmissä (Jewitt, 2014). Tämän seurauksena multimodaalisuuden tutkimuksessa käytetyt käsitteet ovat usein osittain päällekkäisiä toistensa kanssa. Tässä tutkimuksessa merkityksen rakentaminen sekä multimodaalinen viestintä ja diskurssi merkitsevät samaa asiaa. Semioottinen resurssi on "materiaaliresurssien merkityspotentiaali" (ts. viestijän mahdollisia merkityksen tuottamisen valintoja), joka "on kehittynyt ajan myötä yhteisössä käytön kautta ja yhteiskunnan sosiaalisten tarpeiden mukaan" (Jewitt ym., 2016, s. 159). Tässä tutkimuksessa semioottinen resurssi viittaa eri matematiikan oppikirjoissa esiintyviin semioottisiin resursseihin, jotka Joutsenlahden ja Kuljun (2010) matematiikan diskurssin kolmen kielen mallin mukaan ovat symbolikieli, luonnollinen kieli ja kuviokieli (ks. Lemke, 2003; O'Halloran, 2005; Schleppegrell, 2010).

Multimodaalisuutta voi tutkia eri näkökulmista riippuen tutkijan mielenkiinnosta ja tutkimuskohteesta (Jewitt, 2014; Jewitt ym., 2016). Tässä tutkimuksessa hyödynnän systeemis-funktionaalista multimodaalista diskurssinanalyysia (SFMDA), joka on yksi näistä multimodaalisuuden tutkimuksen lähestymistavoista. SFMDA perustuu Hallidayn systeemis-funktionaaliseen teoriaan (SFT). Jewittin, Bezemerin ja O'Halloranin (2016) mukaan SF-MDA -lähestymistavalla pyritään ymmärtämään ja kuvaamaan eri semioottisten resurssien tehtäviä sekä analysoimaan merkityksiä, jotka esiintyvät semioottisten valintojen yhdistyessä multimodaalisissa ilmiöissä. He ovat esittäneet, että multimodaalisissa kielenkäyttötilanteissa teemme kielellisiä valintoja ja käytämme erilaisia resursseja eri funktioissa. Tätä kutsutaan Hallidayn SFT:n mukaan metafunktioksi. Metafunktio jakautuu kolmeen: 
ideationaaliseen, interpersoonaiseen ja tekstuaaliseen (esim. Halliday \& Matthiessen, 2004). Halliday ja Matthiessen (2004) ovat valaisseet jokaista metafunktiota seuraavasti: Ideationaalinen metafunktio ilmaisee ihmisten kokemuksia (maailmaa) ja jakautuu eksperientiaaliseen ja loogiseen. Eksperientiaalinen metafunktio kuvaa tapahtumia, osallistujia ja niihin liittyviä seikkoja (esim. aikaa ja perusteita), kun taas looginen metafunktio luo semanttisia suhteita, siis yhdistää loogisesti tekstissä olevia yksikköjä, kuten tapahtumia tai osallistujia toisiinsa. Interpersoonainen metafunktio puolestaan kuvaa henkilökohtaisia ja sosiaalisia suhteitamme muiden kanssa. Toisin sanoin kielen kautta ilmoitamme tai kysymme, käskemme tai kehotamme sekä ilmaisemme arvostelumme ja asenteemme siihen, kenelle viestimme kohdistetaan ja mistä puhutaan. Tekstuaalinen metafunktio liittyy tekstin rakenteeseen. Se toimii muiden metafunktioiden tukena rakentamalla diskurssin järjestyksiä ja luomalla sujuvuutta, yhtenäisyyttä ja jatkuvuutta.

Shore (2012) on esittänyt, miten Hallidayn metafunktiota voidaan soveltaa suomen kielen tekstianalyysiin. Eksperientiaalisen kielenkäytön tarkastelussa tarkastellaan sanojen valintoja, sanojen välisiä suhteita sekä maailmaa konstruoivia (ekperientiaalisia) lausetyyppejä ( $\mathrm{mm}$. verbi ja siihen kuuluvat välttämättömät lauseenjäsenet). Loogisen metafunktion tarkastelufokukset ovat puolestaan lähinnä lausekkeiden ja lauseiden yhdistelmät, esimerkiksi adverbiaalilause, relatiivilause ja konjunktio. Interpersoonaisen kielenkäytön tarkastelussa keskitytään siihen, miten viestijä suhtautuu oman viestiinsä. Voidaan esimerkiksi tarkastella modaalisia lausetyyppeja (väite-, kysymys-, ja käskylause) ja muita modaalisia valintoja (esim. modaaliset partikkelit, kommenttiadverbiaalit ja sananvalinta). Lisäksi voidaan tutkia modaalisten lausetyyppien ja muiden modaalisten valintojen poissaoloa. Tekstuaalisen kielenkäytön tarkastelussa kiinnitetään huomiota koheesiokeinoihin, teeman- ja informaationkulkuun sekä visuaaliseen ilmeeseen.

Jewitt, Bezemer ja O'Halloran (2016) ovat väittäneet, että semioottisten resurssien kyky toteuttaa metafunktiota ei jakaudu tasaisesti. Heidän mukaansa jotkut resurssit toimivat tietyssä metafunktiossa paremmin kuin toiset, esimerkiksi kieli loogisessa ja kuva eksperientiaalisessa metafunktiossa. He ovat todenneet, että tämän takia multimodaalisen semiotiikan tehokkuus perustuu erilaisten metafunktioiden merkityksen rakentamiskykyihin, joita yksittäisen semioottisen resurssin käytöllä ei ole mahdollista saavuttaa. Heidän mukaansa SF-MDAlähestymistavalla verrataan semioottisia resursseja toisiinsa ja tarkastellaan niiden yhdistämiä multimodaalisten tekstien merkityksiä metafunktioita hyväksi käyttäen. 
Kuitenkin jokaisella semioottisella resurssilla on oma merkitysjärjestelmänsä, analyysiyksikkönsä ja rakenteensa (Jewitt ym., 2016). SF-MDA:ta on sovellettu eri multimodaalisten viestintätoimintojen tarkasteluun, kuten painettujen ja sähköisten tekstien, videoiden ja kolmiulotteisten esineiden analyysiin. Jewitt ym. (2016) ovat huomauttaneet, että tätä lähestymistapaa on kritisoitu lähinnä siitä, että systeemisfunktionaalisen teorian ja metafunktioiden soveltaminen luonnollisen kielen ulkopuolelle ei ole itsestään selvää. Lisäksi he ovat varoittaneet, että tarkastelussa ei saisi keskittyä liikaa yksittäiseen semioottisen resurssin järjestelmään, sillä merkitys on yleensä rakennettu eri semioottisten resurssien järjestelmän yhdistelmästä.

\subsection{Multimodaalisuus matematiikassa}

Matematiikan tekstejä on pidetty multimodaalisena diskurssina, joka koostuu kuten kuvassa 1 pääasiassa matematiikan symbolikielestä (esim. numerot ja matemaattiset symbolit), luonnollisesta kielestä (esim. suomi ja englanti) ja kuviokielestä (esim. kuvia ja diagrammeja) (mm. Joutsenlahti \& Kulju, 2010; O’Halloran, 2005). Esitän ensin jokaisen semioottisen resurssin konventioita (merkitysjärjestelmää ja piirteitä), joita on havaittu aikaisemmissa tutkimuksissa, ja sitten niiden yhdistelmiä kokonaisuutena.

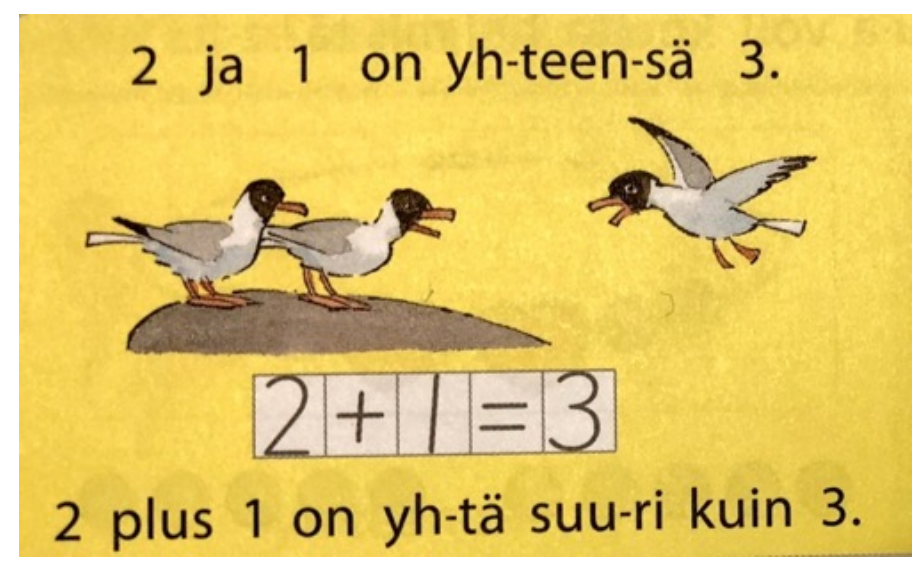

Kuva 1. Eri semioottisten resurssien käyttö matematiikan oppikirjassa (Kymppi 1 syksy, s. 44)

Matematiikan symbolikieli (mathematical symbolism). O'Halloran (2005) on esittänyt, että luonnollisesta kielestä kehitetyn matematiikan symbolikielen tehtävänä on järjestää, mallintaa tilanteita, esittää kuvioita, ratkaista ongelmia sekä 
ennustaa. O’Halloranin (2015a) mukaan symbolikieli keskittyy nimenomaan eksperientiaaliseen ja loogiseen merkitykseen, mutta samalla vähentää interpersoonaista merkitystä (vrt. luonnollisessa esiintyvä kysymys, käsky ja ehdotus), mikä lisää joustavuutta eksperientiaaliseen ja loogiseen merkitykseen. Symbolikielellä esitetään pääasiassa matemaattista tietoa, ilmaistaan absoluuttista modaalisuutta (esim. epävarmuutta ilmaistaan todennäköisyydellä) ja eliminoidaan konteksteja.

Aikaisemmissa tutkimuksissa on havaittu useita matematiikan symbolikielelle tyypillisiä piirteitä. Symbolikieltä luetaan useimmiten vasemmalta oikealle, mutta myös oikealta vasemmalle sekä ylhäältä alaspäin (Meaney, 2005). O’Halloran (2015a) on kuvannut, että symbolinen merkintätapa rakentuu kokonaisuudesta, jossa merkkejä on organisoitu merkityksen rakentamista varten. Hänen mukaansa symboliseen merkintätapaan sisältyy prosessityyppejä, kuten yhteen- ja vähennyslasku. Hän on myös havainnut, että symbolikielen kieliopillisella järjestelmällä matemaattisia suhteita on koodattu täsmällisesti ja yksiselitteisesti. O’Halloran (2015b) on väittänyt, että täsmällisiä ja yksiselitteisiä matemaattisia suhteita ei ole mahdollista ilmaista yhtä helposti luonnollisella kielellä. Lisäksi matemaattinen merkintätapa on eksperientiaalisesti tiheä, sillä jokaisella elementillä on tarkka merkitys suhteessa muihin elementteihin, mutta samalla joustava, sillä elementit voidaan kieliopillisilla strategioilla (esim. sulkeiden käytöllä ja sääntöjärjestyksellä) järjestää uudelleen tarpeen mukaan (Meaney, 2005; O’Halloran, 2015a). Matematiikan symbolisiin ilmaisuihin sisältyy tiheitä nominilausekkeita, jotka viittaavat matemaattisiin operaatioihin (esim. yhteen laskemiseen ja vähentämiseen), sekä relationaalisia (olla ja jollakulla on) ja eksistentiaalisia (olla olemassa) prosesseja ilmaisevia verbejä (O’Halloran, 2005).

Meaney (2005) ja O’Halloran (2005) ovat huomauttaneet, että matematiikan symbolikieli saattaa tuottaa vaikeuksia asiaa tuntemattomalle ja aloitteleville oppijoille seuraavien syiden vuoksi. Uusien symbolien käyttö ja uudet kieliopilliset strategiat (esim. sulkeiden käyttö ja sääntöjärjestys) vaativat opiskelua ja käytön harjoittelua. Tiheä ja moniosainen rakenne edellyttää merkityksen purkamistaitoa. Interpersoonaisen merkityksen niukkuus on vieras viestintätapa monille. Lisäksi matematiikan symbolikielen lukemista ja kirjoittamista ei yleensä muodollisesti opeteta. Sen tähden monilla on vaikea osata hyvin lukea ja kirjoittaa symbolikieltä.

Luonnollinen kieli (language). Matematiikan teksteissä käytettyä luonnollista kieltä on tutkittu Hallidayn systeemis-funktionaalisen lingvistiikan näkökulmasta 
(esim. Meaney, 2005; Morgan, 2006; O’Halloran, 2005). Aiempien tutkimustulosten mukaan matematiikan teksteissä on tiheiksi nominilausekkeiksi muotoiltuja toimintoja sekä suhteita ilmaisevia verbejä (esim. O’Halloran, 2005). Lisäksi teksteissä käytetään usein vierasta tekstirakennetta, arkikäytön kanssa ristiriitaista erikoista terminologiaa (Schleppegrell, 2010) ja varmuutta ilmaisevia modaalisia kielenaineksia, kuten täytyä-verbiä ja välttämätön-adjektiivia (Herbel-Eisenmann \& Wager, 2007). Lisäksi käytetään paljon relationaalisia lauseita ja loogisia konnektiiveja (Meaney, 2005). Tällainen ilmaisu tiivistää matemaattisia tietoja tehokkaasti sekä välittää niitä tietoja täsmällisesti, mutta toisaalta se tekee teksteistä vaikeampia ymmärtää (O’Halloran, 2005).

Matematiikan luonnollisesta kielestä poistetaan usein ihmisen läsnäolo. Teksteissä häivytetään ihmisen toimintoja piilottamalla lauseiden tekijä (HerbelEisenmann \& Wager, 2007; Meaney, 2005; Morgan, 2006) ja tosielämää esitetään vain matematiikan soveltavana esimerkkinä sanallisissa tehtävissä, mikä yleensä häivyttää tekijöiden persoonan ja tilannekontekstin (de-personalization ja decontextualization) (Herbel-Eisenmann \& Wager, 2007). Lisäksi teksteissä ei yleensä esiinny minä-persoona vaan sinä-persoona (Herbel-Eisenmann \& Wager, 2007). Tyypillinen sinä-persoonainen imperatiivilause antaa ymmärtää, että kirjoittaja antaa noudatettavia ohjeita lukijalle (Herbel-Eisenmann \& Wager, 2007; Morgan, 2006; Nugroho, 2010). Edellä mainittujen piirteiden perusteella näyttää siltä, että oppikirjoissa matematiikka asetetaan persoonattomaksi ja objektiiviseksi sekä kirjoittajan ja lukijan välinen suhde vieraantuneeksi.

Kuviokieli (visual images). O’Halloranin (2015b) mukaan kuviokieli on tärkeä matemaattisten suhteiden ja kuvioiden ymmärtämisessä sekä matemaattisessa päättelyssä. Hänen mukaansa kuviokieli konkretisoi abstraktista matemaattista tietoa (mm. käsitteitä ja prosesseja), joka on koodattu symbolikielellä. Lisäksi kuviokieli esittää matemaattisia osia toistensa suhteessa kokonaisuutena (O’Halloran, 2015b). Tämän takia matemaattisiin kuviin sisältyy usein paljon informaatiota, mikä puolestaan saattaa johtaa monimutkaiseen visuaaliseen viestintään (O’Halloran, 2015a).

Kuten muutkin semioottiset resurssit matematiikan teksteissä, kuviokieli on yleensä persoonatonta ja kontekstitonta. Esimerkiksi Herbel-Eisenmann ja Wager (2007) ovat havainneet, että kuvissa esiintyy hyvin vähän ihmisiä ja esiintyvät ihmiset edustavat enimmäkseen ketä tahansa. Lisäksi O'Halloran (2015a, b) on huomauttanut, että yleensä kulttuurinen ja tilanteellinen konteksti poistetaan 
kuvista. O’Halloranin mukaan tämän syynä on, että kuviokielen on johdettava lukijan huomioita täsmällisiin ja yksiselitteisiin matematiikan sisältöihin.

Kuviokielellä on oma merkityksen rakentamisen kieliopillinen järjestelmänsä, joten visuaalisen representaation merkitystä ei voida suoraan rinnastaa verbaaliseen (O'Halloran, 2015a). Lisäksi kuviokieltä on pidetty matematiikassa vähemmän tärkeänä kuin symbolikieltä sen hyödyllisyydestä huolimatta (O'Halloran, 2015b). Kuviokielen asema matematiikassa on parantunut ajan myöten, kun on huomattu, kuinka kuviokieli auttaa matemaattisten käsitteiden merkityksen rakentamisessa. (O’Halloran, 2015a).

Multimodaalinen matematiikan kieli. Symbolikielen, luonnollisen kielen ja kuviokielen esittely erillisinä ei vielä riitä kuvaamaan, miten matematiikassa ilmaistaan merkityksiä. Todellisuudessa eri kielet rakentavat yhdessä matemaattista merkitystä kokonaisuutena, jota ei ole mahdollista ilmaista yksittäisellä semioottisella resurssilla (mm. Lemke, 2003; O’Halloran, 2015a). Jokaisella resurssilla on tietty tehtävä ja rooli matemaattisen merkityksen rakentamisessa. Kuten edellä on esitetty, luonnollista kieltä käytetään esittämiseen, selittämiseen ja perustelemiseen, symbolikielellä ilmaistaan matemaattista kokonaisuutta ja prosessien suhteita sekä saavutetaan ratkaisuja ja kuviokieli taas tekee matemaattisia suhteita näkyväksi. Tämän perusteella voidaan todeta, että matematiikan viestinnässä tarvitaan monilukutaitoa, jolla voi käsitellä multimodaalista merkityksen rakentamisjärjestelmää.

Monissa ehdotetuissa multimodaalisen diskurssin analyysiviitekehyksissä ei yleensä huomioida matematiikan symbolikieltä. Tässä tutkimuksessa sovelletaan O’Halloranin (2005) kehittämää Hallidayn systeemis-funktionaaliseen teoriaan perustuvaa SF-MDA -viitekehystä, jolla voi analysoida kaikkia semioottisia resursseja matematiikan teksteissä ja luokan diskurssissa. Tätä on aiemmin sovellettu singaporelaisen 1. luokan matematiikan oppikirjan multimodaalisuuden tarkasteluun (ks. Nugroho, 2010). 


\section{Menetelmät}

\subsection{Aineisto}

Tutkimusaineistona on tekstejä kolmesta eri matematiikan oppikirjasarjasta 1. ja 4 . luokkien syksylle. Aineistona on seuraavat perinteiset painetut oppikirjat: Sanoma Pron kustantama Kymppi 1 syksy ja 4 syksy, Otavan Tuhattaituri $1 a$ ja $4 a$ sekä Edukustannuksen YyKaаKoo $1 A$ ja NeeViiKuu 4A. Tutkimuksessa ei analysoitu kirjasarjojen e-oppikirjoja. Olen valinnut aineistot tutkimustavoitetta ajatellen. Kaikki tutkitut oppikirjasarjat on laadittu kustantajien mukaan vuoden 2014 opetussuunnitelman mukaisesti. Jotta saisin kattavaa kuvaa oppikirjojen teksteistä, olen valinnut tutkimukseen sekä 1. että 4. luokkien oppikirjoja. 1. luokan oppikirjat edustavat oppimateriaaleja, jotka on tarkoitettu koulutiensä aloittaville oppilaille ja 4. luokan oppikirjat taitavammille oppilaille. Tutkin oppikirjojen multimodaalisuutta pääosin luonnollisten lukujen $(0,1,2,3, \ldots)$ yhteen- ja vähennyslaskuja käsittelevien kirjan lukujen kautta, sillä ne ovat molempien luokka-asteiden opittavia sisältöjä kaikissa kirjasarjoissa. Opetussuunnitelman (Opetushallitus, 2015) mukaan vuosiluokilla 1-2 "kehitetään oppilaiden yhteen- ja vähennyslaskutaitoja... Yhteen- ja vähennyslaskut konkretisoidaan erilaisissa sovellustilanteissa" (s. 129), kun taas vuosiluokilla 3-6 "harjoitellaan yhteen- ja vähennyslaskualgoritmeja" eli laskutoimituksia "sekä varmistetaan niiden osaaminen" (s. 235). Tutkimuksessa tarkastelen vain kaikille oppilaille tarkoitettuja teoriaosia ja perustehtäviä, joita käytetään oppitunneilla. Eriyttävät lisätehtävät ja kotitehtävät jäivät tutkimuksen ulkopuolelle.

\subsection{Metodi}

Tämän tutkimuksen lähestymistapana on monimenetelmä (mixed-methods). Keräsin ja analysoin tutkimusaineistot sekä laadullisesti että määrällisesti. Tarkoituksena oli kerätä monipuolisia aineistoja, jotta voisin kuvata tutkimustuloksia yleisesti ja perusteellisesti (Tuomi \& Sarajärvi, 2018, s. 58). Tutkimusaineiston analyysi jakautui kolmeen vaiheeseen: yleistasoiseen diskurssianalyysiin, sisällön erittelyyn sekä edellisen vaiheen sisällön erittelyn diskurssianalyysiin.

Ensimmäisessä vaiheessa käytin O’Halloranin SF-MDA -viitekehystä (ks. O'Halloranin, 2005) vain suuntaa-antavana, koska tutkimustavoitteenani ei ollut pyrkiä yksityiskohtaiseen matematiikan oppikirjojen multimodaalisen 
tekstiympäristön kuvaukseen vaan saada kokonaiskuva semioottisten resurssien käytöstä ja merkitysten luomisesta sekä semioottisten resurssien käytön monipuolisuudesta. Aluksi tarkastelin eri oppikirjojen tekstiympäristöä yleisellä tasolla, muun muassa rakenteita, sisältöjä ja ulkoasua O’Halloranin viitekehyksen pohjalta. Sen jälkeen tutkin oppikirjoissa esiintyvien semioottisten resurssien (luonnollisen kielen, matematiikan symbolikielen ja kuviokielen) eri tasoisia rakenteita ja niiden käyttöä metafunktiota (ks. alaluku 2.1) ja aiempia tutkimuksia (ks. alaluku 2.2) soveltaen. Tarkastelin aineistosta, miten semioottisia resursseja käytetään rakentamaan metafunktiota eli eksperientiaalista, loogista, interpersoonaista ja tekstuaalista merkitystä. Tarkastelun fokuksessa oli, missä tehtävissä eri resurssit käytetään sekä miten niitä hyödynnetään yhteen- ja vähennyslaskun oppimisessa.

Toinen vaihe oli sisällön erittely (ks. Tuomi \& Sarajärvi, 2018, s. 88), jossa erittelin koko aineiston sisältöjä määrällisesti. Aluksi luokittelin yksittäisen "virkkeen" sen mukaan, onko kyseessä oppilaiden tekstien tulkinta vai tuottaminen. Tämän lisäksi luokittelin jokaisen virkkeen semioottisten resurssien mukaan luonnolliseen kieleen, symbolikieleen ja kuviokieleen. Lopuksi kvalifioin (ks. Tuomi \& Sarajärvi, 2018, s. 99) jokaisen semioottisen resurssin jakautumisen tekstien tulkinnan ja tuottamisen suhteen, jotta voisin määrällisesti verrata tekstiympäristön monipuolisuutta eli eri semioottisten resurssien esiintymistä ja tehtäviä keskenään.

Luokittelin semioottisten resurssien yksittäisiä virkkeitä luonnollisen kielen virkkeen määrittelyn valossa. Isossa suomen kieliopissa (2008, § 864) määritellään, että "virke on tekstin ortografinen rakenneyksikkö", joka voi muodostua lauseesta (esim. Kuinka paljon rahaa jää?) tai lauseista (Kuinka paljon rahaa jää, kun ostos on maksettu?) mutta myös verbittömästä ilmauksesta (esim. yhteenlaskun kertaus) tai yksittäisestä sanasta (esim. yhteenlasku). Aineistossa esiintyvät sanojen lyhenteet (yleiset, kuten $k m, m m, s$. (sivu), $k r$ (kruunu) sekä tapauskohtaiset, kuten $v$ (vastaus), $Y$ (ykköset), $K$ (kymmenet), $S$ (sadat) jne.) tulkitsin luonnolliseksi kieleksi. Luonnollisen kielen virkettä mukaillen määritin, että yksi symbolikielen virke (ts. symbolikielen rakenneyksikkö) voi muodostua matematiikan lausekkeesta (esim. 5, $5 €, 2+3$ tai $2+3+4$ ), yhtälöistä (esim. $2+3=5$ tai $2+3+4=5+4=9$ ) tai lausekkeen arvosta (esim. =5) (Huom. $€$ on luokiteltu symbolikieleen, mutta $k r$ luonnolliseen kieleen). Kuviokielen tapauksessa yksi kuva tai monta kuvaa, jotka muodostavat kokonaisuuden, on yksi kuviokielen virke (ts. kuviokielen rakenneyksikkö). Kuviokielen virkkeiden laskemisessa on käytetty apuna luonnollista ja symbolikieltä. 
Esimerkiksi kuvassa 2 vasemmalla oleva kuva voi ilmaista luonnollisella kielellä "kolme koiraa ja ei yhtään koiraa" ja symbolikielellä " $3+0$ ", vastaavasti oikealla oleva kuva "kaksi palloa, kolme palloa ja yksi pallo" ja "2+3+1". Näin sekä vasemmalla että oikealla oleva kuva on tulkittu yhdeksi virkkeeksi. Tarkastelussa kuvien ja piirroksien lisäksi graafiset elementit (esim. diagrammi, viiva ja värikoodin käyttö) sekä laskuvastausten rengastaminen ja yhdistäminen on tulkittu kuviokieleksi.
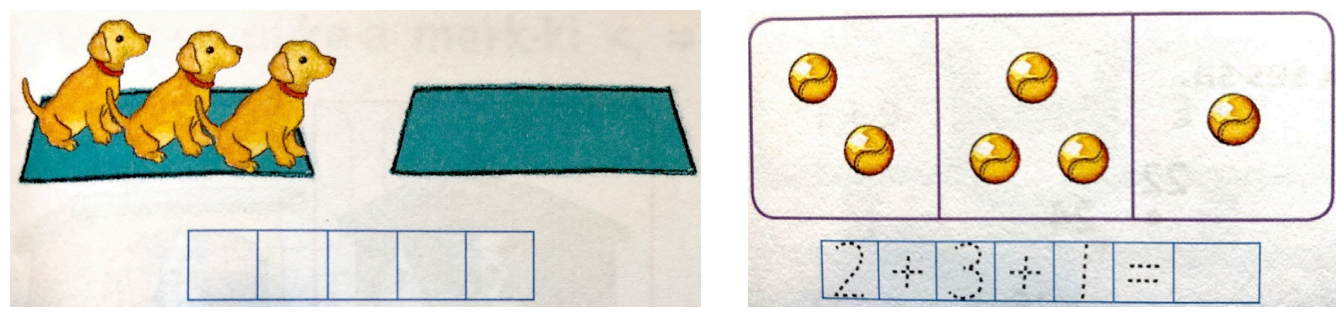

Kuva 2. Yksi kuviokielen virke (Tuhattaituri 1a, ss. 43 ja 158)

Kuten kuvassa 3 kaikki yksittäiset virkkeet muodostuvat yleensä monista semioottisista resursseista. Lisäksi yksi yksittäinen virke toimii usein sekä tulkittavana että tuottavana virkkeenä. Tällaisessa tapauksessa laskennan käytännöllisyyden vuoksi jaoin eri resursseja ja niiden tehtäviä tasaisesti niiden virkkeessä esiintymisosuudesta ja asemasta huolimatta. Esimerkiksi laskin yhden symboli- ja kuviokielellä muodostetun tulkittavan yksittäisen virkkeen, kuten 1 . Kuinka paljon enemmän kirja maksaa kuin lelu? puoleksi symbolikielellä (tehtävän järjestyksen ilmaiseva "1." järjestysluku) ja puoleksi luonnollisella kielellä (luonnollinen kielen lause) muodostetuksi tulkittavaksi virkkeeksi. Kuvan 3 kohdan, jossa yhdistyy lause Vähennä suuremmasta hinnasta pienempi hinta kuvaan puhuvasta kissasta, luokittelin yhdeksi luonnollisella (puhekuplassa oleva ohje oppilaalle) ja kuviokielellä (kissan kuva) muodostetuksi virkkeeksi. Laskin myös yhden symbolikielisen, yksittäisen virkkeen (esim. 6€-4€=_) puoleksi symbolikielellä tulkittavaksi ja puoleksi symbolikielellä tuotettavaksi virkkeeksi. Rajasin pois tekstit, jotka eivät liity suoraan yhteen- ja vähennyslaskun oppimiseen, kuten sivunumerot ja koristavat kuvat. 


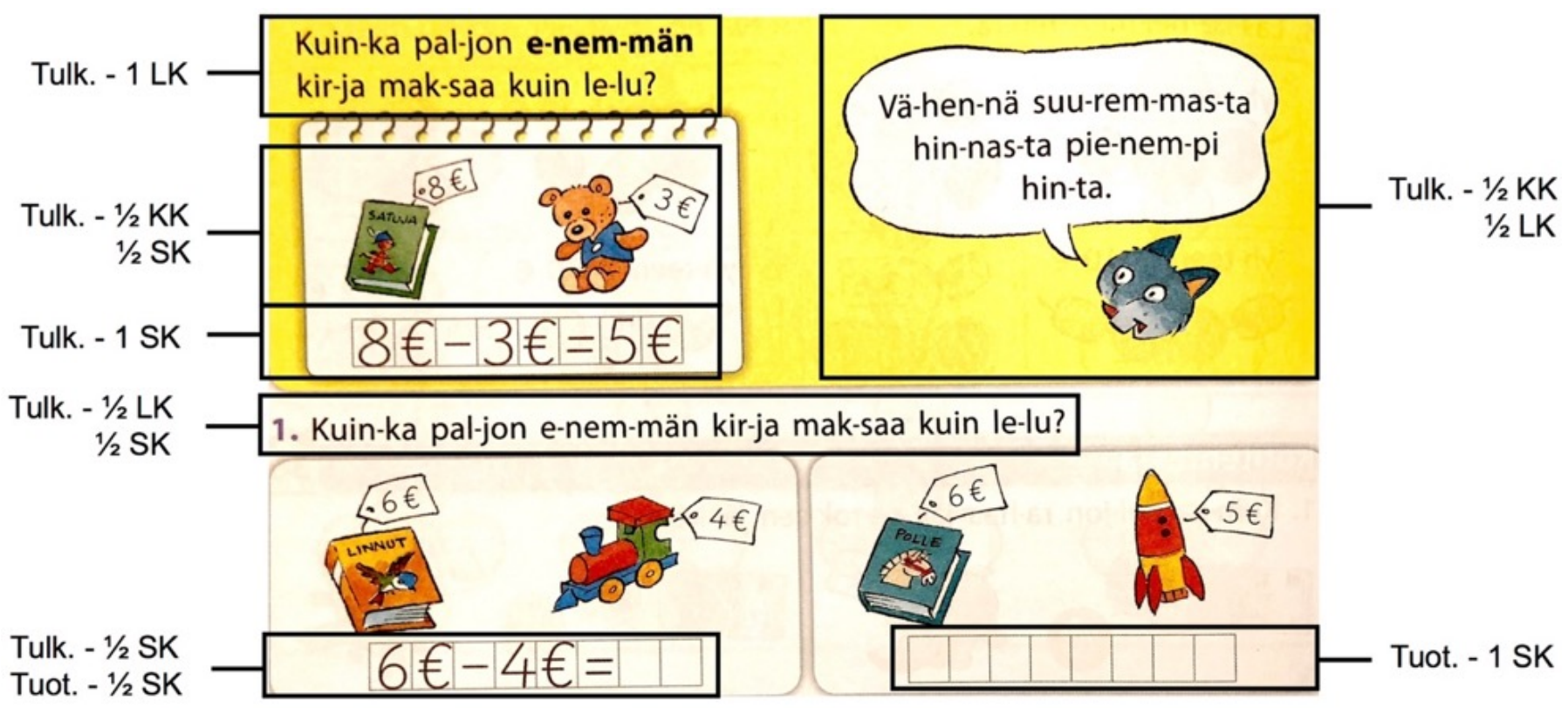

Kuva 3. Esimerkki eri semioottisten resurssien virkkeiden määrän laskemisesta (Kymppi 1 syksy, s. 148) $($ Tulk. = tekstin tulkinta, Tuot. = tekstin tuottaminen, $\mathrm{KK}=$ kuviokielen virke, $\mathrm{LK}=$ luonnollisen kielen virke; SK = symbolikielen virke)

Lopuksi tarkastelin eriteltyjen aineistojen diskurssia eli sitä, millaisissa tehtävissä (tulkinnassa vai tuottamisessa) eri semioottiset resurssit esiintyvät ja millä tavalla. Lisäksi vertasin yksityiskohtaisemmin eri semioottisten resurssien tehtäviä ja esiintymistapoja toisiinsa esimerkkien kautta.

\section{Tulokset}

Tutkimustulokset jakautuvat kahteen osaan. Ensimmäisessä osassa tarkastelen yleisesti oppikirjojen multisemioottista tekstiympäristöä kokonaisuutena ja niissä esiintyviä erilaisia semioottisia resursseja. Toisessa osassa käsittelen tekstiympäristön monipuolisuutta.

\subsection{Multisemioottinen tekstiympäristö}

Tutkimuksen tavoitteena oli selvittää oppikirjojen multisemioottista tekstiympäristöä. Tarkastelen ensin, millaisena tekstiympäristö näyttäytyy kokonaisuutena ja sitten, miten eri semioottisia resursseja (symbolikieltä, luonnollista kieltä ja kuviokieltä) hyödynnetään. Esitän tutkimusaineistojen yhteenvedon oppikirjakohtaisesti eriteltynä taulukossa 1. Taulukosta voi havaita, että eri oppikirjoissa käsitellään luonnollisten lukujen yhteen- ja vähennyslaskuja 
laajuudeltaan vaihtelevasti. 1. luokan oppikirjoissa on ylipäänsä enemmän näitä aiheita käsitteleviä lukuja ja sivuja verrattuna 4. luokan oppikirjoihin. Toisaalta 4. luokan oppikirjoissa on tiheämpiä virkkeitä sivumäärän suhteen kuin 1. luokan oppikirjoissa (virke/sivu: Kymppi 1 syksy=21,9; Tuhattaituri 1a=16,8; YyKaaKoo $1 A=22,2 ;$ Kymppi 4 syksy=22,6; Tuhattaituri 4a=27,6; NeeViiKuu $4 A=25,6$ ).

Taulukko 1. Tutkimusaineistojen (luonnollisten lukujen yhteen- ja vähennyslaskujen käsittelevät teoriaosat ja perustehtävät) yhteenveto oppikirjakohtaisesti.

\begin{tabular}{llllllll}
\hline Oppikirja & Kustantaja & $\begin{array}{l}\text { Paino- } \\
\text { vuosi }\end{array}$ & $\begin{array}{l}\text { Kirjan } \\
\text { lukujen } \\
\text { määrä }\end{array}$ & $\begin{array}{l}\text { Sivujen } \\
\text { määrä }\end{array}$ & $\begin{array}{l}\text { Teoria- } \\
\text { osioiden } \\
\text { määrä }\end{array}$ & $\begin{array}{l}\text { Perus- } \\
\text { tehtävien } \\
\text { määrä }\end{array}$ & $\begin{array}{l}\text { Sivujen } \\
\text { määrä }\end{array}$ \\
\hline $\begin{array}{l}\text { Kymppi 1 } \\
\text { syksy }\end{array}$ & Sanoma Pro & 2016 & 13 & 26 & 6 & 36 & 570 \\
$\begin{array}{l}\text { Tuhattaituri } \\
\text { Ia }\end{array}$ & Otava & 2014 & 8 & 16 & 4 & 17 & 269 \\
$\begin{array}{l}\text { YyKaaKoo } \\
\text { IA }\end{array}$ & Edukustannus & 2017 & 8 & 15 & 3 & 29 & 333 \\
$\begin{array}{l}\text { Kymppi } 4 \\
\text { syksy }\end{array}$ & Sanoma Pro & 2017 & 6 & 12 & 5 & 24 & 271 \\
$\begin{array}{l}\text { Tuhattaituri } \\
\text { 4a }\end{array}$ & Otava & 2015 & 4 & 8 & 3 & 14 & 221 \\
$\begin{array}{l}\text { NeeViiKun } \\
4 A\end{array}$ & Edukustannus & 2014 & 6 & 12 & 6 & 24 & 307 \\
Yhteensä & & & 45 & 89 & 27 & 144 & 1971 \\
\hline
\end{tabular}

Kaikissa oppikirjoissa on kuitenkin hyvin samankaltainen rakenne. Yksi kirjan luku koostuu tyypillisesti kahdesta aukeamasta, jotka on tarkoitettu yhdelle oppitunnille. Ensimmäinen aukeama on aina eräänlainen perusaukeama, joka rakentuu yleensä kolmesta minigenrestä (ks. O’Halloran, 2009): luvun otsikosta, teoriaosasta ja perustehtävästä (ks. kuva 4). 


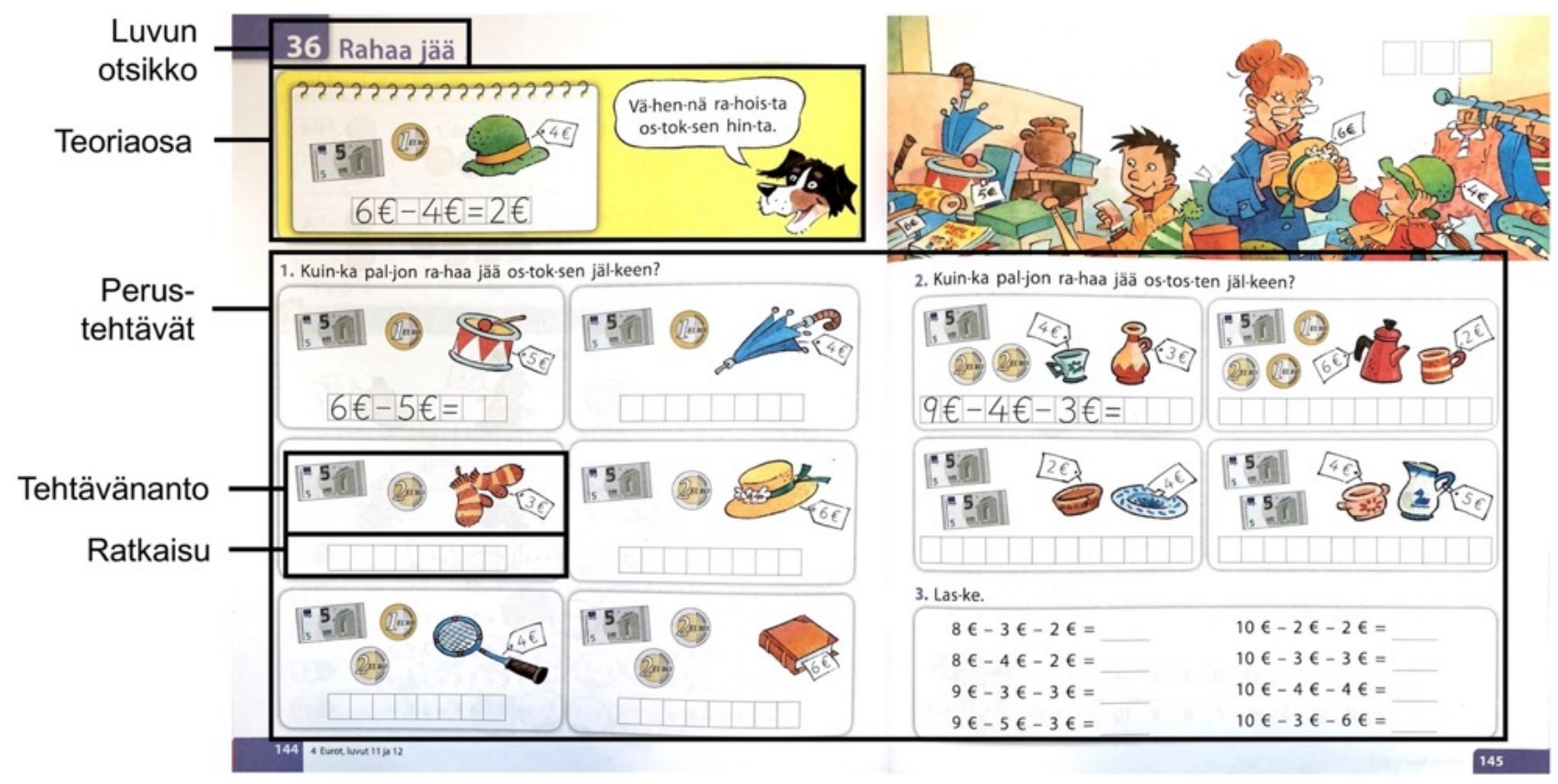

Kuva 4. Oppikirjojen tyypillinen perusaukeama (Kymppi 1 syksy, ss. 144-145).

Kirjan luku alkaa aina sen järjestysluvulla sekä otsikolla, joka suuntaa oppilaita opittavaan aiheeseen. Otsikkoa seuraa yleensä teoriaosa, joka sisältää matemaattisen käsitteen tai operaation kuvauksen ja mahdollisesti esimerkkejä. Teoriaosa erottuu selkeästi muista osista useimmiten omalle alueelle rajaamisella ja kattaa pääosin noin yhden kolmas-kahdesosan sivusta. Teoriaosan jälkeen on numeroituja matemaattisia perustehtäviä, jotka rakentuvat kahdesta osiosta, tehtävänannosta ja tilasta sen ratkaisulle. Yhdessä tehtävässä on yleensä monia samantyyppisiä alatehtäviä. Siksi on vaikeaa vertailla eri oppikirjoissa olevien aineistojen laajuutta tehtävien määrän perusteella. On myös huomioitava, että kertausluvut poikkeavat tästä rakenteesta. Niissä ei ole teoriaosaa vaan aikaisemmin esitettyjen asioiden harjoitustehtäviä.

Perinteisesti oppikirjojen rakenteessa luonnollisella kielellä kirjoitettuja leipätekstejä erotetaan selvästi muista osista. Kuitenkin tutkituissa oppikirjoissa kaikki semioottiset resurssit sijoitetaan lähekkäin toisiaan ja niiden väliset rajat hämärtyvät. Mini-genret erottuvat toisistaan spatiaalisen läheisyyden (esim. rivivälien) ja graafisten elementtien (esim. rajojen) ansiosta (ks. kuvaa 4).

Kaikkien kirjasarjojen matemaattisten käsitteiden ja laskutoimintojen esitykset sekä perustehtävät laaditaan yleensä oppilaita lähellä olevista teemoista eli arkielämän konteksteista, joihin he voivat soveltaa matematiikkaa. 1. luokan kaikissa oppikirjoissa esiintyy oppilaille tuttuja arkipäiväisiä tilanteita, kuten esineiden ja 
eläimien laskemista sekä herkkujen ja lelujen ostamista. 4. luokan oppikirjoissa esiintyvät tilanteet vaihtelevat kirjasarjojen välissä. Kymppi 4 syksy -oppikirjassa kaikki esiintyvät tilanteet liittyvät oppilaiden arkipäivään, esimerkiksi vaatteiden ostamiseen ja lasten lukumäärän vertailuun. Tuhattaituri $4 a$-oppikirjassa esiintyy oppilaille tuttuja kokemuksia, kuten museon kävijöiden määrän sekä automatkan laskemista. Osat NeeVïKuu $4 A$-oppikirjassa esiintyvistä tilanteista (esim. sademäärän vertailu ja paikkakuntien asukasmäärän lasku) sen sijaan ovat jokseenkin kaukana 4. luokkalaisten arkielämästä.

Matematiikan symbolikieli. Kaikissa 1. luokan oppikirjoissa esitetään yhteen- ja vähennyslasku koulun aloittajille ensimmäistä kertaa. Kirjoissa "+" plusmerkki tarkoittaa yhteenlaskuoperaatiota, "-" miinusmerkki vähennyslaskuoperaatiota sekä "=” yhtäsuuruusmerkki yhtä-suuri-kuin -suhdetta. Esimerkkinä "2-1=1" -yhtälöä voidaan pitää yhtenä luonnollisen kielen virkkeenä, jossa kaksi nominilauseketta, "21" ja "1" linkitetään "=", olla-yhtä-suuri-kuin -verbilausekkeella. "=" -merkki on siis kahden nominilausekkeen välisen suhteen ilmaiseva verbi, jota voidaan verrata suhdetta konstruoiviin verbeihin, kuten olla, sisältää ja koostua (vrt. Shore, 2012, s. 165). Samalla "2-1" -nominilauseke tarkoittaa operaatiota, jossa kahdesta vähennetään yksi. Matematiikan lausekkeissa lukusanoja (esim. yksi ja kaksi) ei käytetä ilmaisemaan jonkun substantiivin lukumäärää (esim. kaksi lintua), vaan itsenäisinä substantiiveina (esim. kaksi plus yksi). Lisäksi kirjoissa olevat tehtävät, kuten " $2+1=\ldots$ _ antavat oppilaalle ohjeen, jonka mukaan hänen on suoritettava matemaattinen operaatio tässä tapauksessa "lisätään yksi kahteen", jotta saisi tehtävän ratkaistua. Tämän jälkeen kirjoissa esitetään, että yhteen- ja vähennyslaskuoperaatio voi olla ketjuna. Esimerkkinä "4+3-2" -lauseke tarkoittaa sitä, että ensin lisätään kolme neljään ja sitten vähennetään kaksi edellisen operaation tuloksesta. Kaikissa 4. luokan oppikirjoissa esitetään, että yhtäsuuruussuhde voi myös olla jatkumona, esimerkiksi "90+25=90+20+5=115". Lisäksi kirjoissa käsitellään myös yhteen- ja vähennyslaskun merkintöjä allekkain, jota luetaan ylhäältä alaspäin. Oppikirjojen lukemisen ja ymmärtämisen lisäksi oppilaan on osattava myös muodostaa itse matematiikan lausekkeita.

Luonnollinen kieli. Se, että kaikki oppikirjat on tarkoitettu alakoululaisille, näkyy erilaisten strategioiden käytöstä oppilaiden lukemisen ja ymmärtämisen helpottamiseksi. Kaikissa oppikirjoissa käytetään vain isoja kirjasinkokoja ja yksinkertaisia pääteviivattomia (sans-serif) kirjasintyyppejä. 1. luokan oppikirjoissa käytetään tavuviivoja. Lauserakenteen osalta hyödynnetään useimmiten avainsanoja 
laskutoimintojen vihjeinä (esim. yhteenlasku: tulee lisää, yhteensä ja yhteis-; vähennyslasku: pois, jää ja jäljellä sekä vertailu: enemmän, vähemmän ja -ero), jotta semanttiset suhteet olisivat selkeät oppilaalle. Laskutoimituksen ohjeita annetaan yleensä vaiheittain, esimerkiksi Vä-hen-nä en-sin 2 ja sit-ten vie-lä 3. (Kymppi 1 syksy, s. 104).

Lisäksi kaikissa oppikirjoissa suuri osa virkkeistä on lyhyitä ja yksinkertaisia, esimerkiksi Kuin-ka mon-ta e-nem-män on pul-lia kuin kek-se-jä? (YyKaaKoo 1A, s. 116). 4. luokan oppikirjojen virkkeet ovat hiukan pidempiä ja monimutkaisempia kuin 1. luokan, esimerkiksi Kuinka monta tuntia enemmän aurinko paistaa Maarianhaminassa kuin Kööpenhaminassa? (NeeViiKuu 4A, s. 33). Oppikirjojen virkkeet rakentuvat yleensä yhdestä lauseesta. Poikkeuksena Tuhattaiturikirjasarjassa esiintyy muutamia yhdyslauseita. Tästä esimerkkinä on seuraava virke: Kuin-ka pal-jon ra-haa jää, kun os-tos on mak-set-tu? (Tuhattaituri 1a, s. 75).

Yhteen- ja vähennyslaskun käsitteitä selitetään vain 1. luokan oppikirjoissa. Kaikkien oppikirjojen käsitteiden selitykset ovat suhdelauseita (ks. Shore, 2012, s. 165), joissa hyödynnetään suhdetta konstruoivaa verbiä olla. Predikaattina olla-verbi kertoo lauseen subjektin ja predikaatin takana olevien lauseenjäsenten suhteesta, esimerkiksi Yh-teen-las-kun tu-los on sum-ma. Kak-si plus kol-me on yh-tä suu-ri kuin vii-si. (YyKaaKoo 1A, s. 60).

Yleensä oppikirjoissa ihmisen persoona ja tilannekonteksti häivytetään pois. Käsitteiden selityksissä väitelauseen tekijöinä ei ole ihmisiä, vaan matemaattisia elementtejä, esimerkiksi Vä-hen-nys-las-kun tulos on e-ro-tus. Kol-me miinus yk-si on yh-tä suu-ri kuin kak-si (YyKaaKoo 1A, s. 68). Esimerkeissä ja sanallisissa tehtävissä olevat ihmiset ovat yleensä yleisnimellä, kuten lapsi, aikuinen, taikuri ja katsoja. Lisäksi sanallisissa esimerkeissä ja tehtävissä annetaan pelkästään tarvittavat tiedot ratkaisua varten, esimerkiksi Atte juoksi tiistaina $6 \mathrm{~km}$ ja torstaina 7 km. Kuinka monta kilometriä hän juoksi yhteensä? (Tuhattaituri 4a, s. 7). Kuten edellisissä esimerkeissä lauseet ovat lähinnä kolmannessa persoonassa. Poikkeavasti Kymppi-kirjasarjassa esiintyy kirjasarjan hahmojen erisnimiä sekä minä- ja sinäpersoona, kuten Kuinka monta keksiä jää? Syön 2. (Kymppi 1 Syksy, s. 73) ja Poimit 2 sientä. Kuinka monta jää? (s. 57).

Laskutoimitusten sekä tehtävien tehtävänannoissa hyödynnetään pelkästään sinä- ja te-persoonaisia käskyilmauksia. Lähes kaikki ohjeet ovat lyhyitä imperatiivilauseita, esimerkiksi Laske., Tee yhteenlasku. ja Ratkaiskaa yhdessä. 
Kuviokieli. Kaikissa oppikirjoissa hyödynnetään kuviokieltä monin tavoin moniin tarkoituksiin. Kohta b kuvassa 5 on 1. luokan oppikirjojen tyypillinen tapa käyttää kuviokieltä visualisoimaan yhteen- ja vähennyslaskun käsitteitä sekä laskutehtäviä. Tässä tarkoituksessa käytetään värikkäitä esineiden, eläinten ja ihmisten piirroskuvia, joiden merkityksettömät osat, kuten taustat, pelkistetään.

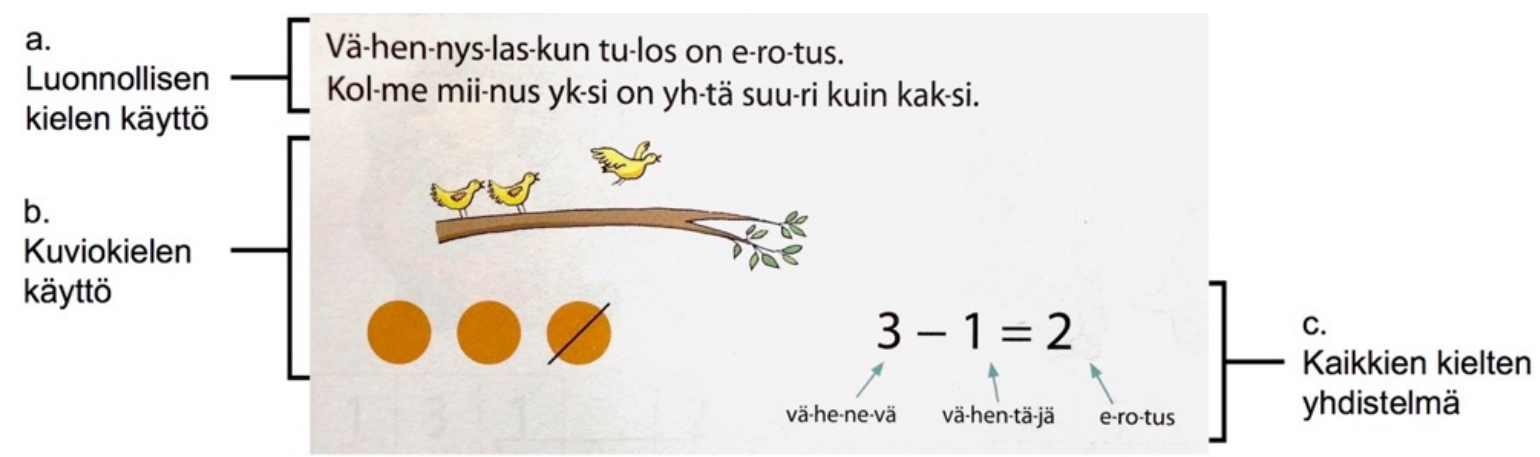

Kuva 5. Semioottisten resurssien käyttö vähennyslaskun teoriaosassa (YyKaaKoo 1A, s. 68).

Yhden tarinamaisen kuvan (esim. kohta b kuvassa 5) lisäksi parissa oppikirjoissa hyödynnetään sarjakuvamaisia kuvia. Esimerkiksi kuvassa 6 merkitys koostuu kolmesta kuvasta, jotka kertovat 3-vaiheista yhteenlaskuun liittyvää tarinaa.

\section{Ker-ro ku-vis-ta ta-ri-na. Tee yh-teen-las-ku.}

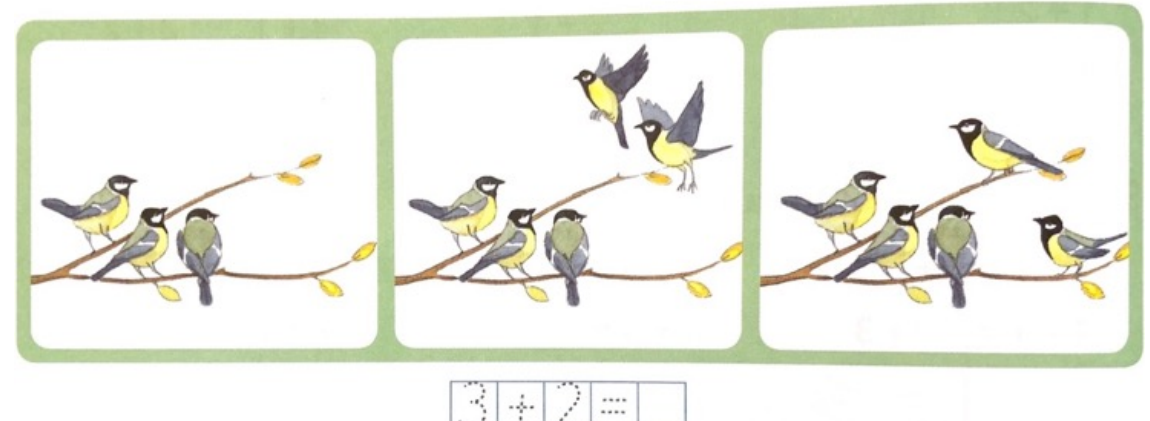

Kuva 6. Sarjakuvamainen kuviokieli yhteenlaskun harjoituksessa (Tuhattaituri 1a, s. 54).

4. luokan oppikirjoissa 1. luokan oppikirjoille tyypilliset kuvat vähentyvät. Kaikissa kirjasarjoissa käytetään lähinnä abstraktia grafiikkaa, ympyröitä, viivoja ja värikoodia samaan tarkoitukseen eli ikään kuin aloittaville lukijoille sanallisena tarinana (esim. kohdan b alaosa kuvassa 5). Molempien luokka-asteiden oppikirjoissa käytetään 
myös matemaattisen lausekkeen yhteydessä esineiden ja eläimien kuvia tai grafiikkaa, joiden määrä vastaa symbolikielellä kirjoitettu lukua. Tallainen havainnollinen kuva auttaa oppilasta konkreettisesti hahmottamaan lukukäsitettä. Kuviokielen lukemisen lisäksi tehtävien tekemisessä oppilaan tulee myös osata käyttää omien ratkaisujen ilmaisemisessa.

Multimodaalinen matematiikan kieli. Kaikissa oppikirjoissa esiintyy eri semioottisten resurssien yhdistelmiä, jotka rakentavat yhdessä matematiikan merkitystä kokonaisuutena. Yksi multimodaalinen virke rakentuu usein kahdesta tai kolmesta semioottisesta resurssista, jotka täydentävät toisiaan.

Suuri osa kahden semioottisen resurssin virkkeistä ovat luonnollisen kielen virkkeitä, joissa käytetään symbolikieltä peruslukuna tai järjestyslukuna. Esimerkiksi kohta b kuvassa 7 on sanallinen tehtävä 3., jonka luonnollisen kielen avulla annetussa tehtävänannossa esiintyy peruslukuja tyttöjen ja poikien määränä. Lisäksi oppikirjoissa esiintyy myös kuvia, joissa osana on symbolikieltä tai luonnollista kieltä, kuten kohta c kuvassa 7 on diagrammi, jonka tehtävänä on visualisoida sanallisen tehtävän laskutoimituksia. Oppilaan on selvitettävä diagrammin puuttuvat luvut sanallisen tehtävän perusteella.

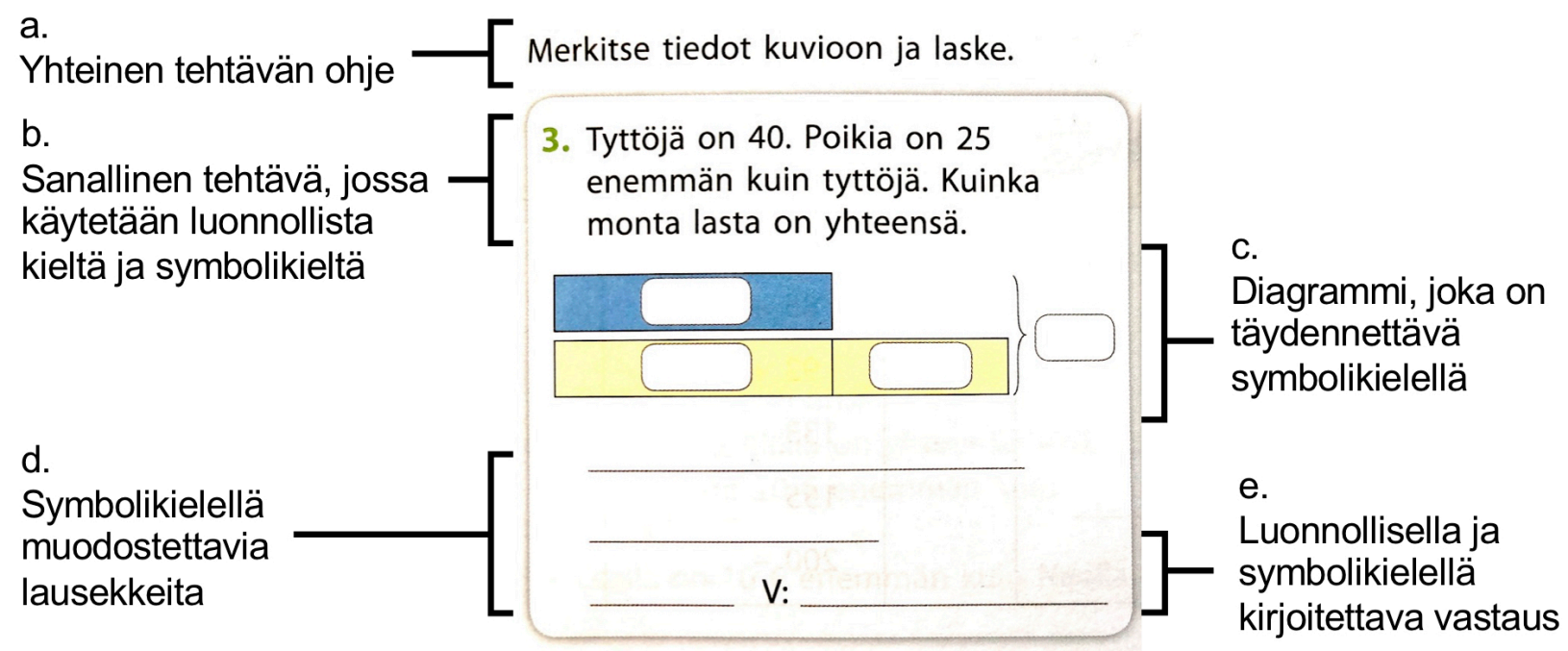

Kuva 7. Diagrammi ja symbolikielellä laskeminen sanallisessa tehtävässä (Kymppi 4 syksy, s. 17). 
Kymppi ja Tuhattaituri -kirjasarjoissa luodaan interpersoonaista merkitystä käyttämällä hahmojen kuvia puhekuplan kanssa antamaan ystävällisellä tavalla ohjeita laskutoimituksista teoriaosassa tai tehtäviin liittyvää lisätietoa tehtävänannossa (esim. puhuva kissa kuvassa 3 ja koira kuvassa 4). Erityisesti kuvan 8 kohdassa c puhuvan oravan lisäksi on myös kaksi iloista tietokoneen ääressä istuvaa lasta. Kuvassa olevat lapset eivät ainoastaan edusta oppilaita vaan myös viittaavat siihen, että matematiikka on kivaa.

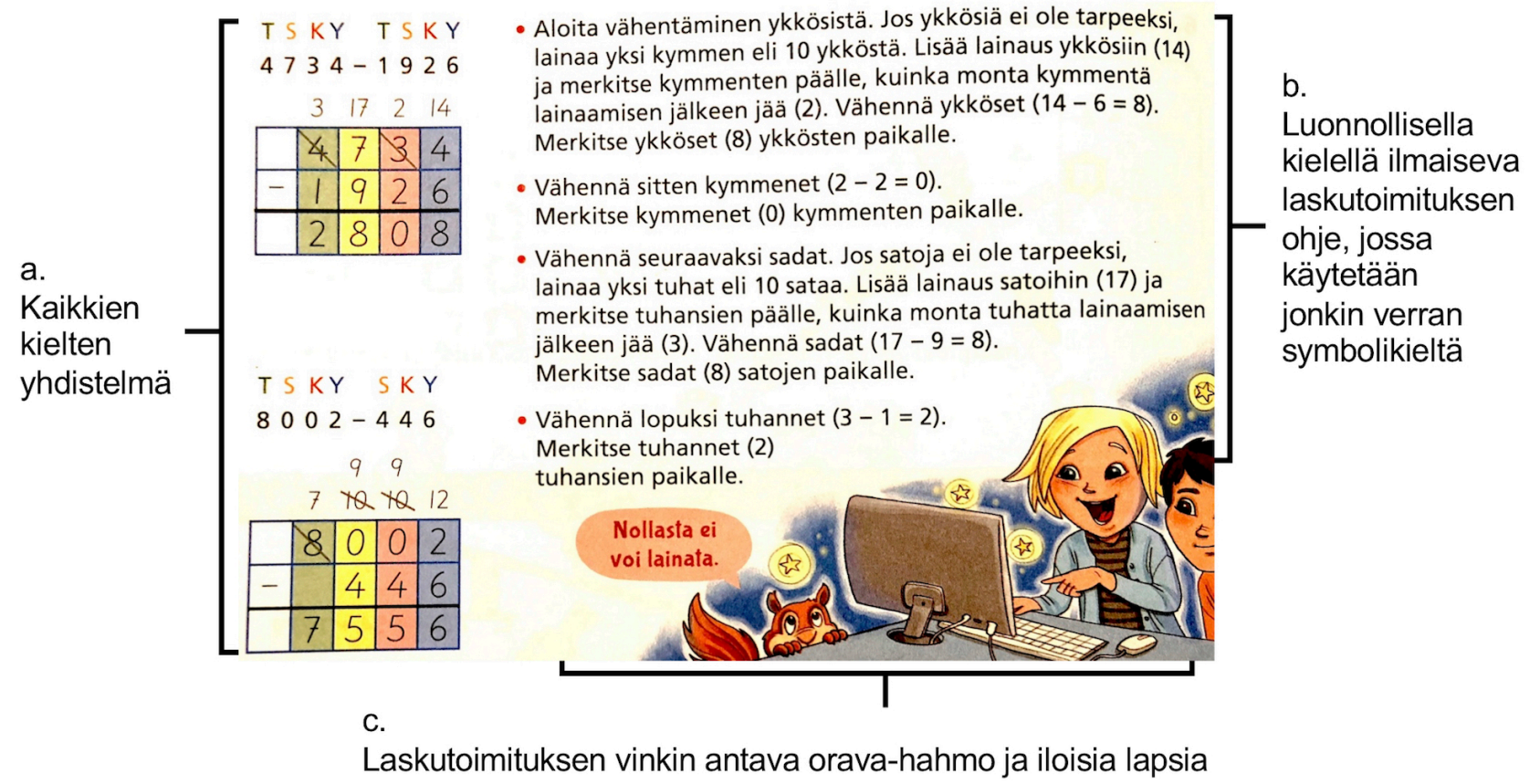

Kuva 8. Semioottisten resurssien käyttö vähennyslaskun teoriaosassa (Tuhattaituri 4a, s. 66).

Monesti symbolikieltä käytetään kuviokielen virkkeen osana. Esimerkiksi kuvan 9 kohdassa b symbolikieli toimii esineiden hintalappuna. 
a.

Yhteinen tehtävänanto luonnollisella kielellä ja symbolikielikielellä

b.

Symbolikieli kuviokielen virkkeen osana

c.

Symbolikielellä täydennettäviä lausekkeita
[2. Las-ke hin-ta-e-ro.

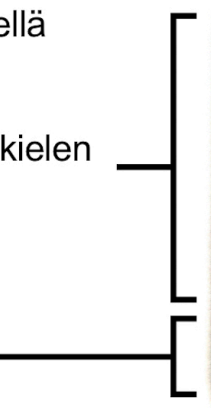

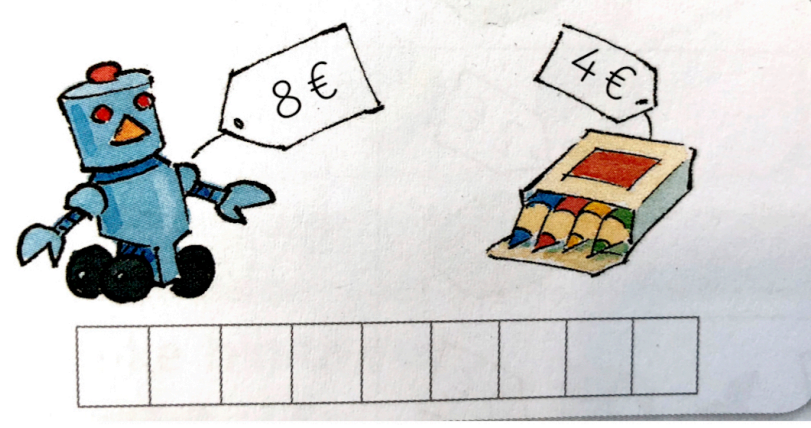

Kuva 9. Semioottisten resurssien käyttö vähennyslaskun teoriaosassa (Tuhattaituri 4a, s. 66).

Oppikirjoissa symbolikieli, luonnollinen kieli ja kuviokieli yhdistyvät toisiinsa monin tavoin. Kuvan 5 kohdassa c käytetään kaikkien kielten yhdistelmää vähennyslaskun osien esittelyssä. Kohta a kuvassa 8 on laskutoimituksen ohje, jossa hyödynnetään symbolikieltä, luonnollista kieltä (ykkösten, kymmenten, satojen ja tuhansien lyhenteet) ja kuviokieltä (värikoodia ja asettelua) yhdistelmänä. Kuvan 10 kohta c on madon kuva, jossa on annettavia yhteenlaskujen vastauksia (symbolikielisiä) ja kirjaimia (luonnollisia kieliä) niiden pareina. Kuvan kohdassa b oppilaan tulee parittaa saamansa symbolikielinen vastaus kohdassa c annetun kirjaimen kanssa.

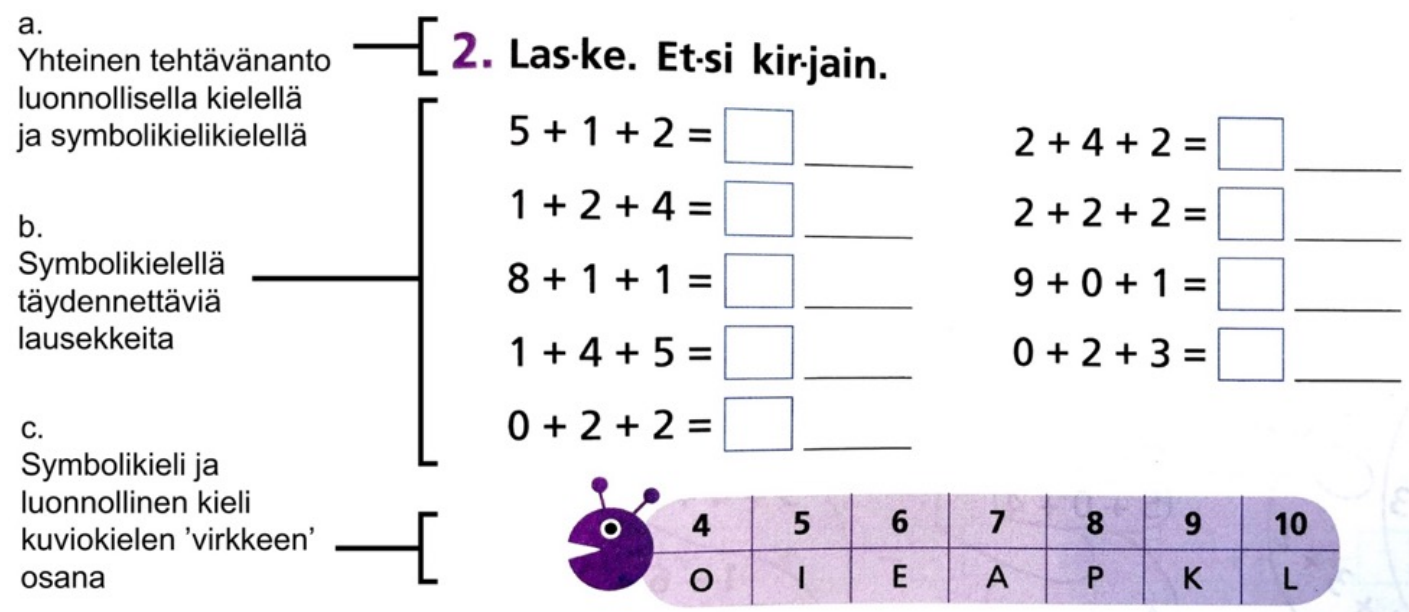

Kuva 10. Semioottisten resurssien käyttö yhteenlaskun tehtävissä (Tuhattaituri 1a, s. 159). 
Lisäksi kahdessa 4. luokan oppikirjassa tehtävänanto-osion osina esiintyy kolmen kielen yhdistelmiä taulukoina, joihin sisältyy informaatiota tiheästi. Esimerkiksi kuvassa 11 oleva taulukko antaa oppilaille tarvittavat tiedot yhteen- ja vähennyslaskuja varten. Lisäksi kuvassa on myös taulukossa mainittujen maiden kartta ja lippu lisäkuvaelementteinä.

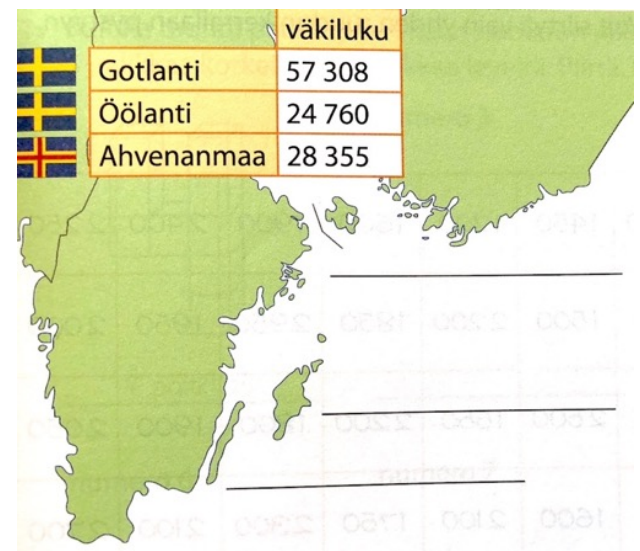

Kuva 11. Semioottisten resurssien käyttö yhteenlaskun tehtävissä (Tuhattaituri 1a, s. 159).

\subsection{Tekstiympäristön monipuolisuus}

Tutkimuksen tavoitteena oli myös selvittää sitä, kuinka monipuolista tekstiympäristöä oppikirjat tarjoavat oppilaalle. Ensin tarkastelen semioottisten resurssien monipuolisuutta tekstien tulkinnassa ja sitten tehtävien tuottamisessa.

Tekstien tulkinta. Kuvassa 12 olevassa pylväsdiagrammissa verrataan oppikirjakohtaisesti tekstien tulkinnan semioottisten resurssien jakautumista prosentteina. Diagrammista voidaan havaita, että 1. luokan oppikirjojen välillä semioottiset resurssit jakautuvat hyvin samansuuntaisesti, kun taas 4. luokan oppikirjojen välillä esiintyy enemmän variaatiota. 


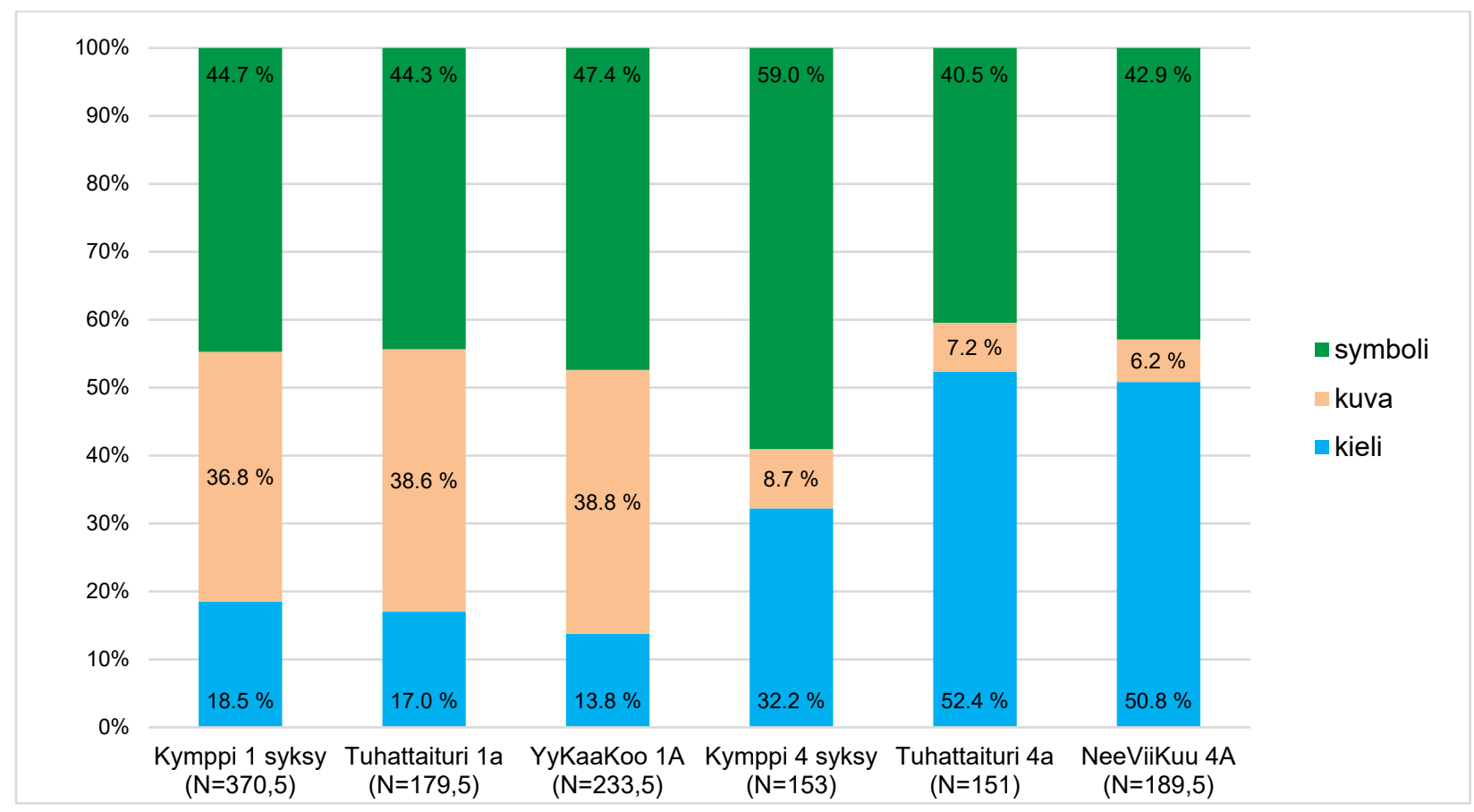

Kuva 12. Tekstien tulkinnan semioottisten resurssien jakautuminen eri oppikirjoissa.

Jokaisen 1. luokan oppikirjan tekstien tulkinnassa esiintyy eniten matemaattista symbolikieltä (Kymppi 1 syksy:ssä 44,7 \%, Tuhattaituri 1a:ssa 44,3 \% ja YyKaaKoo 1A:ssa $47,4 \%$ ), jonka osuus on melkein puolet kaikista esiintyvistä semioottisista resursseista. Oppikirjoissa symbolikieltä käytetään eniten valmiiksi annetun matemaattisen laskulausekkeiden osana, esimerkiksi kohta d kuvassa 13 "7-2-3=_". Lisäksi symbolikieltä esiintyy tehtävänannossa yhdistelmänä muiden semioottisten resurssien kanssa. Multimodaalisia tehtävänantoja esiintyy eniten Kymppi 1 syksy oppikirjassa, esimerkiksi kuvan 13 kohdassa b on symbolikieltä luonnollisen kielen lauseen osana, kohdassa c kuviokieltä ja kohdassa d matemaattisia lausekkeita. 


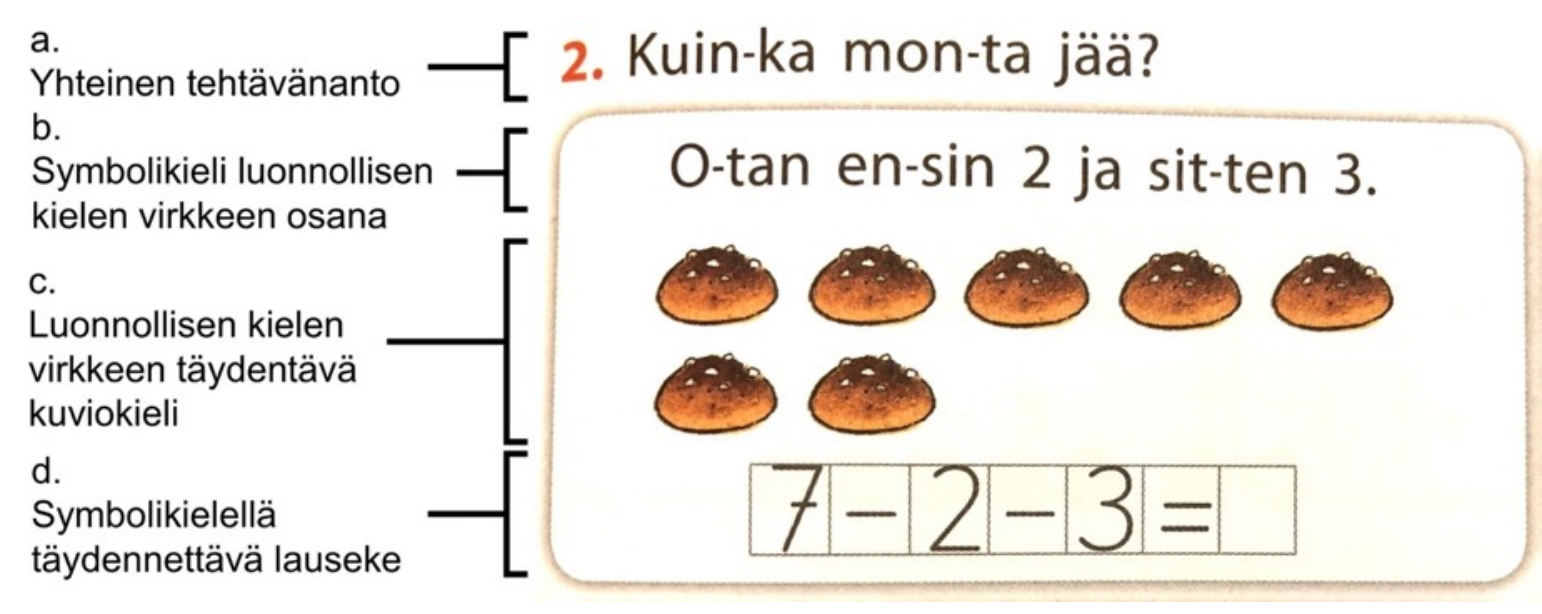

Kuva 13. Semioottisten resurssien esiintyminen tekstien tulkinnassa (Kymppi 1 Syksy, s. 105).

Toiseksi eniten esiintyy kuviokieltä (Kymppi 1 syksy:ssä 36,8 \%, Tuhattaituri 1a:ssa 38,6 \% ja YyKaаKoo 1A:ssa 38,8 \%). Oppikirjoissa kuviokieltä käytetään visualisoimaan yhteen- ja vähennyslaskuja teoriaosissa (esim. kuva 4) sekä laskutehtävissä (esim. kuva 6). Vähiten esiintyy luonnollista kieltä (Kymppi 1 syksy:ssä 18,5 \%, Tuhattaituri 1a:ssa 17,0 \% ja YyKaaKoo 1A:ssa 13,8 \%), jonka osuus on reilu yksi kuudesosa kaikista esiintyvistä semioottisista resursseista. Luonnollista kieltä on pääsäännöllisesti otsikoissa, teoriaosien selityksissä sekä tehtävien ohjeissa (ks. kuvaa 4). Ainostaan Kymppi 1 syksy -oppikirjassa luonnollista kieltä käytetään myös alatehtävien osana (esim. kohta b kuvassa 13).

4. luokan oppikirjojen tekstien tulkinnassa kuviokielen käyttö laskee huomattavasti. Kaikissa oppikirjoissa vähiten esiintyvä semioottinen resurssi on kuviokieli (Kymppi 4 syksy:ssä 8,7 \%, Tuhattaituri 4a:ssa 7,2 \% ja NeeViiKuu 4A:ssa 6,2 \%). Näyttää siltä, että 1. luokan oppikirjoille tyypillinen kuviokielen käyttö korvataan myöhemmin muilla semioottisilla resursseilla. Tuhattaituri $4 a$ ja NeeViiKuu $4 A$-oppikirjoissa yli puolet tekstien tulkinnasta on luonnollista kieltä $(52,4 \%$ ja 50,8 \% vastaavasti). Kirjojen teoriaosissa esiintyy paljon enemmän luonnollista kieltä 1. luokan oppikirjoihin verrattuna (vrt. kohta b kuvassa 8 kohtaan a kuvassa 5). Lisäksi molemmissa oppikirjoissa 1. luokan oppikirjoissa aloittaville lukijoille sanallisina tehtävinä toimivat kuvat korvataan kokonaan luonnollisella kielellä. NeeVïKuu $4 A$-oppikirjan tehtävänannossa käytetään myös taulukoita (esim. kuva 11), joissa vaaditaan oppilaalta erilaista tekstien tulkinnan osaamista kuin esimerkiksi luonnollisella kielellä kirjoitetussa tekstin osissa. Tuhattaituri $4 a$ ja NeeViiKuu $4 A$-oppikirjojen symbolikielen käytön osuus (40,5 \% ja 42,9 \% 
vastaavasti) pysyy melkein samana kuin 1. luokan oppikirjoissa. Molemmissa oppikirjoissa matemaattinen symbolikieli toimii 1. luokan oppikirjoissa olevien tapaan.

Kymppi 4 syksy -oppikirjan eniten esiintyvä semioottinen resurssi on symbolikieli (59,0 \%), ja sitä käytetään samoin kuin muissakin oppikirjoissa. Tässä oppikirjassa kuviokieli toimii muiden semioottisten resurssien kanssa tehtävänannossa (esim. kohta a kuvassa 14), mutta sen käytön osuus $(8,7 \%)$ pienentyy suhteessa 1 . luokan kirjaan. Diagrammia käytetään sanallisten tehtävien osina kuten kuvan 7 esimerkissä. Lisäksi monissa luvuissa hyödynnetään myös taulukoita tehtävänannon osina. Oppikirjassa luonnollisen kielen käytön osuus lisääntyy jonkin verran (32,2 \%) verrattuna Kymppi 1 syksy -kirjaan (18,5\%). Luonnollinen kieli toimii enimmäkseen tehtävien ohjeissa sekä sanallisissa tehtävissä (esim. kohta a-b kuvassa 7).

a.

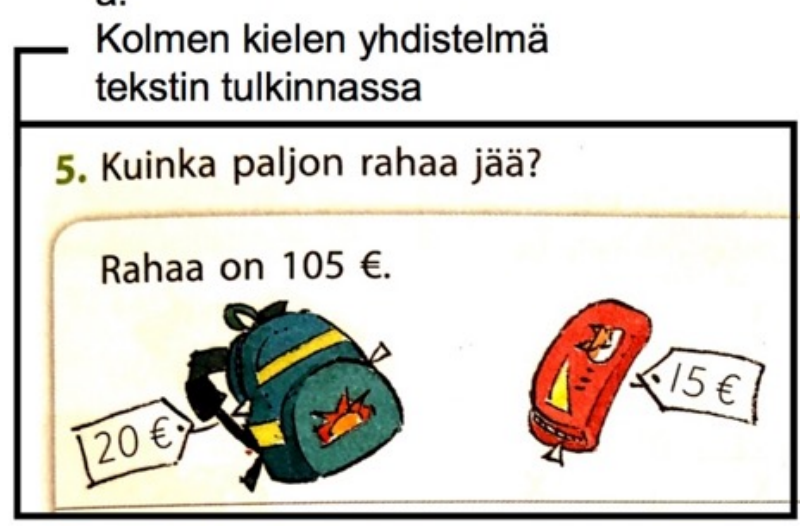

Kuva 14. Kuviokielen käyttö muiden kielten kanssa tehtävänannossa (Kymppi 4 syksy, s. 17). b.

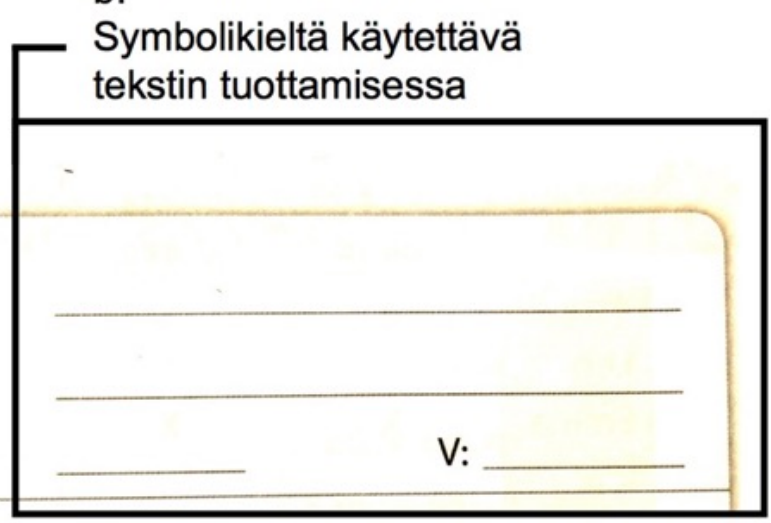

Tehtävien tekstien tuottaminen. Kuvassa 15 oleva pylväsdiagrammi kuvaa oppikirjakohtaisesti tekstien tuottamisen semioottisten resurssien jakautumista prosentteina. Diagrammissa on selvästi nähtävissä, että jokaisessa oppikirjassa tekstien tuottaminen painottuu matemaattisen symbolikielen käyttöön (Kymppi 1 syksy:ssä 100,0 \%, Tuhattaituri 1a:ssa 80,4 \%, YyKaaKoo 1A:ssa 80,9\%, Kymppi 4 syksy:ssä 97,7 \%, Tuhattaituri 4a:ssa 76,2\% ja NeeViiKuu 4A:ssa 77,9 \%). Oppilaan on tuotettava symbolikieltä tehtävissä, joissa annetaan valmiiksi matemaattinen laskulauseke, jonka vastaus (ts. lausekkeen arvo) pitää laskea ja merkitä, esimerkiksi "=" -merkin jälkeen (esim. kohta d kuvassa 13). Lisäksi oppilaan tulee käyttää symbolikieltä lausekkeiden muodostamisessa, muodostamiensa lausekkeiden 
laskussa sekä laskemansa laskun vastauksessa (esim. kohta d-e kuvassa 7 ja kohta b kuvassa 14).

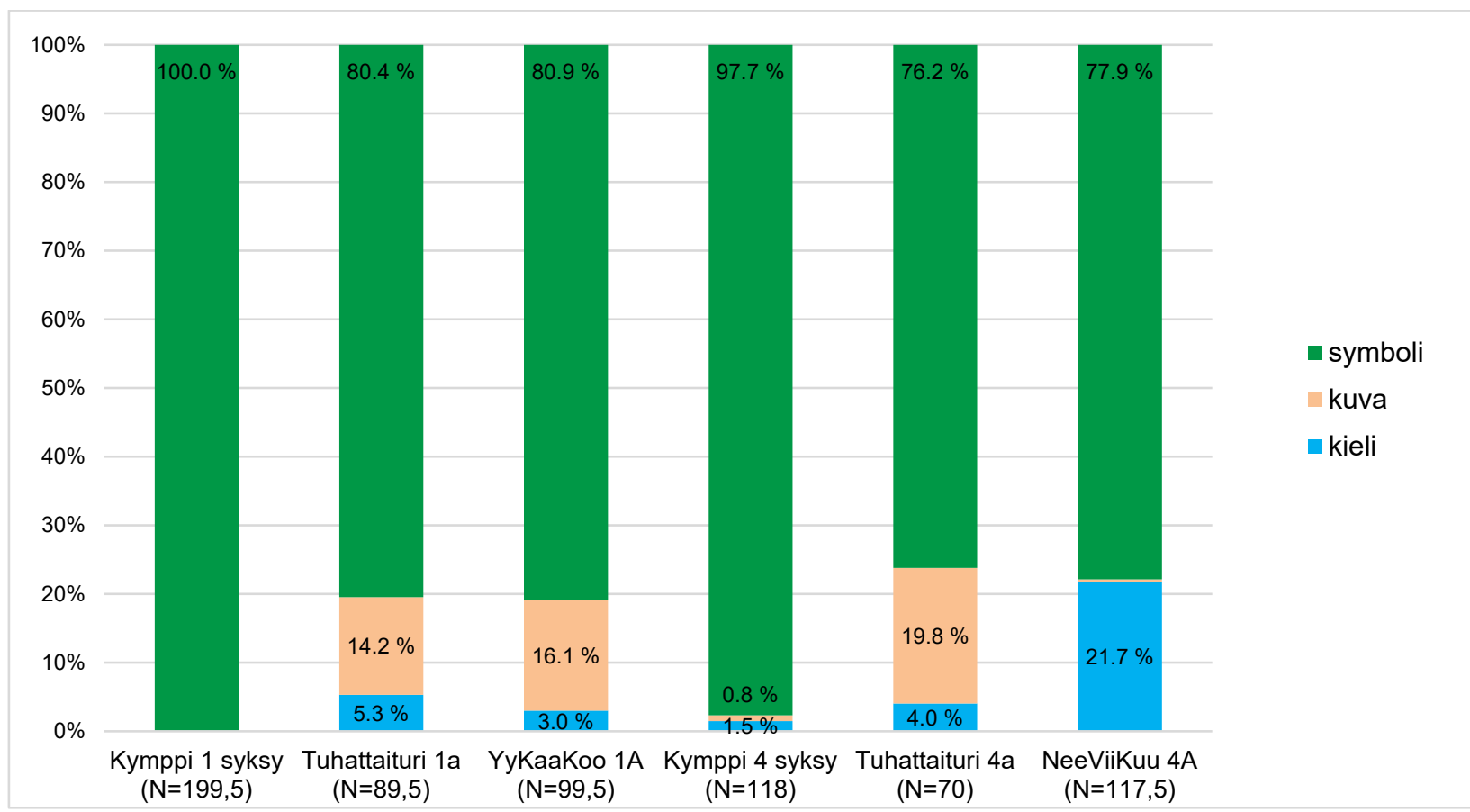

Kuva 15. Tekstien tuottamisen semioottisten resurssien jakautuminen eri oppikirjoissa.

On kuitenkin huomattava, että symbolikieltä vähempikäyttöisten luonnollisen kielen ja kuviokielen tekstien tuottaminen vaihtelee paljon oppikirjoittain. Kymppikirjasarja eroaa selkeästi muista edellyttämällä oppilaalta pääasiallisesti symbolikielen tuottamista. Kymppi 1 syksy -oppikirjassa oppilaan ei juurikaan tarvitse tuottaa tekstejä muilla semioottisilla resursseilla. Vaikka Kymppi 4 syksy oppikirjaan sisältyy jokin verran oppilaan muiden kielten ilmaisuja (kuviokielen o,8 \% ja luonnollisen kielen 1,5 \%), ne ovat vain oikean vastauksen ympyröityminen ja laskuvastausten yksikkö (esim. kohta e kuvassa 7 "V: 105 lasta”). Tuhattaituri $1 a$ ja YyKaаKoo $1 A$-oppikirjoissa hyödynnetään jonkin verran oppilaan ilmaisuja muilla semioottisilla resursseilla kuin symbolikielellä. Näissä oppikirjoissa oppilaan on ilmaistava kuviokielellä (Tuhattaituri 1a:ssa 14,2 \% ja YyKaaKoo 1A:ssa 16,1 \%). Laskujen vastauksen yhdistämisen lisäksi Tuhattaituri 1 a -oppikirjassa oppilaan on vedettävä oikea määrä viivoja esineiden yli vähennyslaskussa (esim. kuva 16). 


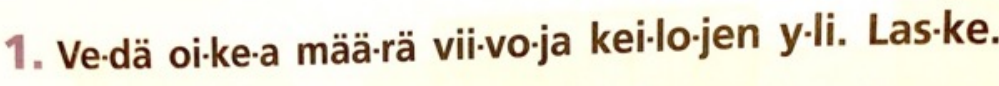

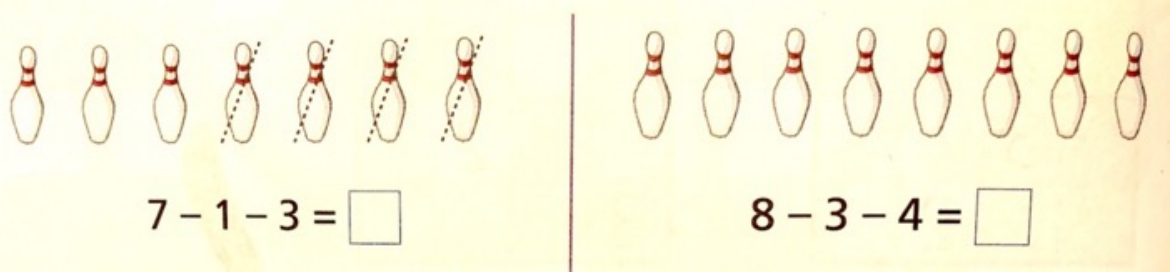

Kuva 16. Kuviokielen tuottaminen vähennyslaskussa (Tuhattaituri 1a, s. 162).

Yhtäläisesti YyKaaKoo $1 A$-oppikirjassa oppilaan on piirrettävä kuvia annetuista yhteen- ja vähennyslaskuista (esim. kuva 17). Luonnollisella kielellä ilmaisun osalta Tuhattaituri 1 a -oppikirjassa (5,3\%) oppilaan tulee vain parittaa symbolikielinen vastaus annetun kirjaimen kanssa (esim. kuva 10), kun taas YyKaaKoo $1 A$ oppikirjassa (3,0 \%) on kerrottava tai kirjoitettava oma yhteenlaskutarina (ts. muodostettava itse sanallinen tehtävä).

\section{Piir-rä ku-va yh-teen- ja vä-hen-nys-las-kus-ta.}

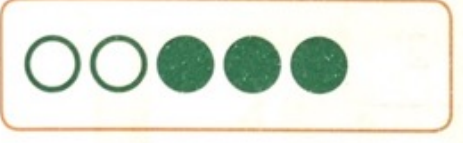

$2+3=5$

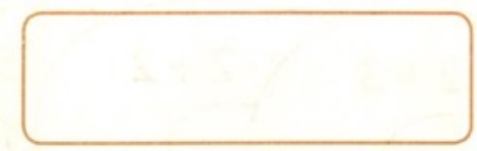

$4+1=5$

Kuva 17. Kuviokielen tuottaminen yhteenlaskussa (Tuhattaituri 1a, s. 81).

Tuhattaituri $4 a$-oppikirjassa oppilaan kuviokielellä ilmaisu (19,8 \%) lisääntyy jonkin verran 1. luokan oppikirjasta, mutta 4. luokan oppikirjassa oppilaan on kuitenkin käytettävä kuviokieltä pelkästään symbolikielisten laskuvastausten rengastamisessa. NeeViiKuu $4 A$-oppikirjassa oppilaan kuviokielellä ilmaisu (0,4 \%) vähenee huomattavasti YyKaaKoo $1 A$-kirjasta (16,1\%). 4. luokan oppikirjassa oppilaan tulee yhdistää symbolikielisiä lukuja, jotta niiden summa tai erotus on yhtä suuri kuin tehtävänannossa annettu luku. Tuhattaituri $4 a$-oppikirjassa oppilaan luonnollisella kielellä ilmaisu (4,0 \%) pysyy melkein samana kuin 1. luokan oppikirjassa (5,3 \%). NeeVïKuu $4 A$-oppikirjassa se (21,7 \%) taas selvästi lisääntyy 1. luokan oppikirjasta (3,0 \%). Tuhattaituri $4 a$-oppikirjassa oppilaan on kirjoitettava laskuvastausten yksikkö luonnollisella kielellä. Laskuvastausten yksikön kirjoittamisen lisäksi 
NeeViiKuu $4 A$-oppikirjassa on käytettävä luonnollista kieltä vihkotehtävien sivunumeron ja tehtävänumeron kirjoittamisessa (esim. s. 62, 1 a. eli sivussa 62 tehtävä 1 a). Tässä oppikirjassa on ainakin yksi tehtävä, jossa oppilaan on keksittävä ja sitten kirjoitettava laskutarina (ts. oma sanallinen tehtävä).

\section{Pohdinta}

\subsection{Millaisia semioottisia resursseja oppikirjoissa on ja miten niitä hyödynnetään merkitysten luomisessa?}

Tarkasteltu tekstiympäristö on pääosin samanlainen kuin aikaisemmissa tutkimuksissa. Kaikissa oppikirjoissa esiintyy eri minigenrejä jokaisessa kirjan luvussa (ks. Nugrohon, 2010), jossa hyödynnetään eri semioottisia resursseja (ks. Joutsenlahti \& Kulju, 2010; Lemke, 2003; O’Halloran, 2005; Schleppegrell, 2010). Tekstien osien (mm. resurssien, osioiden ja minigenrejen) välinen rajaus hämärtyy (ks. Nugrohon, 2010). Lisäksi tosielämän tilanteita käytetään matematiikan soveltavina esimerkkeinä (ks. Herbel-Eisenmann \& Wager, 2007) oppilaiden ikätaso huomioiden, mikä vastaa hyvinkin opetussuunnitelman (Opetushallitus, 2015) vuosiluokkien 1-2 yhteen- ja vähennyslaskujen konkretisoimisen tavoitteeseen.

Kaikissa oppikirjoissa matematiikan symbolikielen käyttö tukee aikaisimpien tutkimusten väitteitä. Ilmeisesti symbolikieli on täsmällinen ja vankka mutta samalla joustava työkalu (ks. Meaney, 2005; O’Halloran, 2015a, 2015b), jota voidaan käyttää omalla lauseopilla ilmaisemaan yksiselitteisesti matemaattisia suhteita ja operaation prosesseja, kuten yhteen- ja vähennyslaskujen lausekkeiden tulkitsemista ja muodostamista (ks. O’Halloran, 2005). Symbolikieltä luetaan sekä vasemmalta oikealle että ylhäältä alaspäin (ks. Meaney, 2005). Lisäksi symbolikielisissä ilmaisuissa interpersoonainen merkitys häivytetään, kun taas matematiikan elementtejä, kuten lukuja, inhimillistetään eli lukusanat toimivat itsenäisinä substantiiveina (ks. O'Halloran, 2015a).

Yleisesti ottaen kaikissa oppikirjoissa oleva luonnollinen kieli on yksikertaista, ytimekästä ja helppoa ymmärtää. Tämä on sopusoinnussa Joutsenlahden ja Kuljun (2010) sekä Nugrohon (2010) tutkimusten kanssa. Kuitenkin se poikkeaa monista aikaisemmista tutkimuksista (vrt. Meaney, 2005; Morgan, 2006; O’Halloran, 2005), joiden aineistot on kerätty lukion tai yliopiston oppimateriaaleista. Niiden tutkimusten mukaan lukio- ja yliopistomatematiikan tekstit ovat yleensä 
monimutkaisia ja tiheää tietoa sisältäviä, mikä tekee teksteistä vaikeampia ymmärtää. Samoin kuin aikaisemmissa tutkimuksissa (esim. Meaney, 2005; Morgan, 2006; O’Halloran, 2005) tutkituissa oppikirjoissa luonnollinen kieli ilmaisee yleensä matemaattisia suhteita ja operaatioita. Lisäksi oppikirjoissa esiintyvät ihmisen persoonan ja tilannekontekstin häivyttämisseikat ovat samat kuin aikaisemmissa tutkimuksissa (ks. Herbel-Eisenmann \& Wager, 2007; Joutsenlahti \& Kulju, 2010; Meaney, 2005; Morgan, 2006). Samankaltainen käskyilmaus onkin havaittu aikaisemmissa tutkimuksissa (ks. Herbel-Eisenmann \& Wager, 2007; Morgan, 2006; Nugroho, 2010). Tässä tutkimuksessa monet luonnolliseen kieleen liittyvät seikat ovat sopusoinnussa Joutsenlahden ja Kuljun (2010) sekä Nugrohon (2010) tutkimusten kanssa, mutta poikkeavat monista aikaisemmista tutkimuksista matematiikan tekstien yksikertaisuuden ja ymmärtämisen helppouden suhteen (vrt. Meaney, 2005; Morgan, 2006; O’Halloran, 2005). Tämä saattaa johtua siitä, että tämän, Joutsenlahden ja Kuljun (2010) ja Nugrohon (2010) tutkimuksen aineistot on kerätty alakoulun oppikirjoista, kun taas muiden aineistot lukion tai yliopiston oppimateriaaleista.

Tässä tutkimuksessa kuviokielen käyttöön liittyvät seikat ovat samoja kuin mitkä on havaittu aikaisemmissa tutkimuksissa. Ensinnäkin kuviokieli tekee matemaattisia suhteita näkyviksi ja konkreettisiksi (ks. O’Halloran, 2015b). Lisäksi keskittymistä matemaattisiin suhteisiin ja kokonaisuuteen helpotetaan selkeyttämällä esitettyjä kuvia yksinkertaistamalla niitä ja poistamalla epäoleellisia konteksteja (ks. HerbelEisenmann \& Wager, 2007; O’Halloran, 2015a, 2015b). Kuitenkin näyttää siltä, että tässä tutkimuksessa oppikirjojen kuvien abstraktioaste sekä kuvien sisältämä tietomäärä suunnitellaan oppikirjojen kohderyhmät huomioiden. Tässä sekä Nugrohon (2010) tutkimuksessa käytetyt kuvat eivät ole täysin pelkistettyjä, vaan värikkäitä piirrettyjä hahmoja, eläimiä ja esineitä, mikä saattaa johtua siitä, että molempien tutkimuksissa tutkitut oppikirjat on tarkoitettu alakoululaisille.

Samoin kuin aikaisemmissa tutkimuksissa kaikissa oppikirjoissa esiintyy eri semioottisten resurssien yhdistelmiä, jotka rakentavat yhdessä matematiikan merkitystä kokonaisuutena (ks. Lemke, 2003; O’Halloran, 2015a). Tutkittujen oppikirjojen multimodaalisissa virkkeissä on selkeästi yksi dominoiva semioottinen resurssi ja muut resurssit esiintyvät sitä täydentävinä. Tyypillisesti luonnollinen kieli (esim. kuvan 7 kohta b) tai kuviokieli on dominoiva (esim. kuvan 8 kohta c). Toisinaan oppikirjoissa esiintyy myös multimodaalisia virkkeitä, joista on vaikea päätellä, mikä on virkkeen dominoiva resurssi, kuten kuvan 7 kohdan c diagrammi ja kuvan 11 
taulukko. Diagrammi ja taulukko onkin luokiteltu kuviokieleksi, mutta kun tarkastellaan niissä käytettyjen semioottisten resurssien suhdetta, vaikuttaa siltä, että kaikilla resursseilla on yhtä tärkeä rooli merkitysten luomisessa. Semioottisten resurssien intersemiotiikan tarkastelu, joka on rajattu pois tästä tutkimuksesta, olisi valaissut semioottisten resurssien vuorovaikutusta ja niiden välisiä suhteita.

\subsection{Kuinka monipuolisesti semioottisia resursseja hyödynnetään oppikirjoissa?}

1. luokan oppikirjojen tekstien tulkinnassa ei esiinny paljon luonnollista kieltä vaan enimmäkseen symbolikieltä ja kuviokieltä. Tämä tutkimustulos on 1. luokan oppimateriaalia ajatellen ymmärrettävä, sillä oppikirjat on tarkoitettu aloittaville lukijoille. Sen tähden luonnollista kieltä käytetään yleensä yksikertaisissa muodoissa ja välttämättömissä tilanteissa. Esimerkiksi kohdassa a kuvassa 13 alatehtävien yhteinen sanallinen tieto ja kohdassa c mahdollinen sanallinen tieto korvataan kuvilla. Toisaalta osaaville lukijoille tarkoitetuissa 4. luokan oppikirjoissa luonnollisen kielen tulkinta lisääntyy. Kuviokielen tulkinta taas laskee huomattavasti (vrt. Kautto \& Peltoniemi, 2006, s. 92), mutta symbolikielen käyttö pysyy melkein samana. Multimodaalisen matematiikan kielen osalta 1. luokan oppikirjoissa esiintyy luonnollisen kielen virkkeitä, joissa käytetään symbolikieltä peruslukuna tai järjestyslukuna sekä piirrettyjä kuvia, joissa käytetään symbolikieltä (esim. hintana) tai luonnollista kieltä (esim. puheena). 1. luokan oppikirjoissa esiintyvien tekstien lisäksi 4. luokan oppikirjoissa esiintyy myös diagrammeja ja taulukoita.

Tekstien tuottamisessa symbolikieli dominoi ylivoimaisesti molempien luokkaasteiden oppikirjoissa. Vaikka muutamat oppikirjat pyrkivät huomioimaan oppilaan luonnollisen ja kuviokielen tuottamista tehtävissä, molempia kieliä ei määrältäkään eikä laadultakaan hyödynnetä monipuolisesti. Tähän voi olla mahdollisena syynä, että matematiikan oppikirjoissa keskitetään ensisijaisesti yhteen- ja vähennyslaskun oppimiseen ja harjoitteluun.

Davisin (ks. O’Halloranin, 2015b, ss. 295-296) sekä Kuljun ja Joutsenlahden (2010, s. 169) mukaan matemaattista symbolikieltä pidetään merkittävimpänä semioottisena resurssina matemaattisten tulosten johtamisessa. Vaikka tässä tutkimuksessa merkitykset rakennetaan kaikkien semioottisten resurssien avulla, voidaan kuitenkin päätellä semioottisten resurssien tulkinnan ja tuottamisen jakautumisesta, että matemaattisella symbolikielellä on keskeinen rooli kaikissa 
tutkituissa oppikirjoissa. Oppikirjojen tekstien tulkinnassa on monipuolisempi tekstiympäristö verrattuna tekstien tuottamiseen. Siitä huolimatta 4. luokan oppikirjojen tekstien tulkinnassa semioottisten resurssien monipuolisuus laskee. On kuitenkin huomioitava, että tekstien tulkinta ja tuottaminen sekä eri semioottisten resurssien käyttö ovat osin päällekkäisiä (esim. kohta c kuvassa 5 ja kohta a kuvassa 14). Lisäksi symbolikielen ja kuviokielen virkkeen rajaaminen on tehty tutkijan toimesta tulkinnanvaraisesti lingvistiikkaa soveltamalla, joten määrälliset tutkimustulokset ovat vain suuntaa-antavia.

\section{Johtopäätökset}

Opetussuunnitelma 2014 (Opetushallitus, 2015) esittää, että oppilaan monilukutaidon kehitys edellyttää monipuolisen tekstiympäristön tulkintaa ja tuottamista. Opetussuunnitelma kannustaa oppilasta ilmaisemaan matemaattisia ratkaisujaan ja päätelmiään multisemioottisia resursseja hyödyntäen, esimerkiksi suullisesti, kirjallisesti ja piirtäen. Lisäksi on todettu, että Suomessa matematiikan opetus on oppikirjapainotteista (esim. Joutsenlahti \& Vainionpää 2010). Tutkimuksen tavoitteena oli selvittää, vastaako uuden opetussuunnitelman mukaan tehtyjen alakoulun oppikirjojen tekstiympäristö näitä esitettyjä periaatteita, toisin sanoen, kuinka oppikirjat tarjoavat oppilaalle mahdollisuuden multimodaalisten tekstien tulkintaan ja tuottamiseen.

Tutkimuksen mukaan alakoulun oppikirjoissa olevilla teksteillä on hyvin samanlaisia piirteitä kuin aikaisemmissa tutkimuksissa, joissa on tutkittu eri kouluasteiden oppikirjoja. Yhteiset esiintyvät piirteet ovat muun muassa eri semioottisten resurssien käyttö, tosielämän tilanteitä soveltavat esimerkit, interpersoonaisen merkityksen vähäisyys, täsmällinen symbolikieli, matemaattisten suhteiden ja operaatioiden ilmaisu luonnollisella kielellä sekä matemaattisten suhteiden visualisointi ja konkreettisointi kuviokielellä. Kuitenkin tässä tutkimuksessa esiintyy myös muutamia seikkoja, jotka poikkeavat monien aikaisempien tutkimusten tuloksista oppikirjojen kohderyhmän erosta johtuen, esimerkiksi matematiikan tekstien yksikertaisuus ja ymmärtämisen helppous. Ylipäänsä voidaan sanoa, että multimodaalisuuden kannalta tutkituissa oppikirjoissa monipuolisia tekstiympäristöjä huomioidaan hyvin vähän. Matematiikan symbolikieli dominoi ylivoimaisesti, erityisesti tekstien tuottamisessa, muut semioottiset resurssit taas jäävät vähemmälle. Esimerkiksi vaikka 
opetussuunnitelman mukaan taulukoihin ja diagrammeihin tutustuminen on jo matematiikan alkuopetuksen yksi tavoite (Opetushallitus, 2015, s. 129), niitä ei esiinny missään tutkituista 1. luokan oppikirjoista. Samoin 4. luokan oppikirjoissa niitä esiintyy vain jonkin verran (ks. myös Kautto \& Peltoniemi, 2006, s. 93). Tutkimustulosten valossa voidaan todeta, että tutkitut oppikirjat eivät vastaa hyvin opetussuunnitelman monilukutaidon tavoitteeseen. Kaikissa oppikirjoissa eri semioottisia resursseja hyödynnetään enimmäkseen vain tarpeiden mukaan, siis lähinnä oppilaan luku- ja laskutaitojen perusteella, esimerkiksi 1. luokan oppikirjoissa käytetään paljon kuviokieltä, joka auttaa koulun alokasta lukemaan ja laskemaan, kun taas 4. luokan oppikirjoissa 1. luokan oppikirjojen samantapainen käyttö vähenee, koska lukemisen ja laskemisen taitava ei tarvitse enää sitä apua. Lisäksi semioottisia resursseja hyödynnetään myös matematiikan opetettavia sisältöjä ajatellen, esimerkiksi vuosiluokilla 1-2 yhteen- ja vähennyslaskutaitojen kehittämisen ja yhteen- ja vähennyslaskujen konkretisoimisen (ks. Opetushallitus, 2015, s. 129) sekä vuosiluokilla 3-6 yhteen- ja vähennyslaskutoimitusten harjoittamisen ja niiden osaamisen varmistamisen (ks. s. 235).

On syytä kiinnittää huomiota siihen, että multimodaalisuudella on suuri merkitys oppilaalle multimodaaliseksi muuttuvassa tekstimaailmassa (Opetushallitus, 2015) sekä oppilaan matemaattisessa ajattelussa ja käsitteiden ymmärtämisessä (Joutsenlahti \& Kulju, 2010; Morgan, 2001). Siitä huolimatta näyttää siltä, että matematiikan oppikirjat ovat usein oppiainekeskeisiä, toisin sanoen ne keskittyvät pääsäännöllisesti pelkästään matemaattisiin sisältöihin, vaikka opetussuunnitelman (Opetushallitus, 2015) mukaan opetettavien sisältöjen lisäksi matematiikan opetuksen tehtävänä on myös kehittää oppilaan monilukutaitoa sekä matemaattista ajattelua ja matemaattisten käsitteiden ymmärtämistä. Edellä esitettyjen perusteella oppikirjojen tekstiympäristö voisi olla multimodaalisempi. Oppikirjat voisivat tarjota oppilaalle enemmän multimodaalista luettavaa. Lisäksi tehtäviä suorittaessaan oppilas voisi käyttää symbolikielen lisäksi enemmän myös luonnollista kieltä ja kuviokieltä ilmaisemaan ratkaisujaan.

Voi olla, että oppikirjojen tekijät ovat käyttäneet semioottisia resursseja kirjojen kohderyhmää ajatellen, esimerkiksi he saattavat olettaa, että 1. luokkalaiset eivät osaa vielä lukea. Tästä syystä 1. luokan oppikirjoissa käytetään hyvin vähän kirjoitettua luonnollista kieltä. Toisaalta on muistettava, että oppilaiden luku- ja kirjoitustaito on heterogeenista. Monet 1. luokkalaiset osaavat lukea ja kirjoittaa jo ennen koulua. Lisäksi luonnollisella kielellä kirjoittamisen sijaan 1. luokkalaiset voisivat myös 
tuottaa tekstejä suullisesti. On myös huomioitava, että vaikka 4. luokan taitavat lukijat eivät tarvitse enää sanallisten tehtävien kaltaisia kuvallisia tehtäviä (esim. kuva 6). He voisivat kuitenkin hyödyntää kuviokieltä matematiikan kannalta mielekkäästi muissa muodoissa, kuten diagrammeja (esim. kuva 7) ja taulukkoja (esim. kuva 11).

Toisaalta uuden opetussuunnitelman mukaista monilukutaitoa ei ole mahdollista saavuttaa pelkästään matematiikan oppikirjojen kautta. Opetussuunnitelman (Opetushallitus, 2015) mukaan sitä kehitetään kaikilla luokka-asteilla ja kaikissa oppiaineissa. Matematiikan kannalta oppikirjojen lisäksi multimodaalista osaamista voisi kehittyä myös esimerkiksi luokan yhteistoiminnassa ja ryhmätyöskentelyssä.

Tämän tutkimuksen luotettavuutta nostavat osaltaan tutkimuksen monitriangulaatio: tutkimusaineisto- ja metodologinen triangulaatio (ks. Tuomi \& Sarajärvi 2018, ss. 125-126). Tutkimusaineisto on kerätty kolmen eri oppikirjasarjan kahden luokka-asteen oppikirjoista samalta osa-alueelta. Monimenetelmätutkimuksen seurauksena määrälliset ja laadulliset tutkimustulokset todistavat ja täydentävät toisiaan. Lisäksi tutkimusaineistot on analysoitu ja tarkasteltu SF-MDA -viitekehyksen ja aikaisempien tutkimustuloksien pohjalta. Sekä SF-MDA -viitekehys että aikaisemmat tutkimustulokset antoivat hyvän pohjan diskurssianalyysiin. Ne muun muassa ohjasivat tarkastelufokuksia sekä auttoivat diskurssianalyysin tulkinnoissa. Kuitenkin on huomioitava, että olen tehnyt diskurssianalyysin ja sisällön erittelyn yksin. Luokittelu olisi ollut luotettavampi, jos analyysissa olisi ollut myös toinen analysoija. Siitä huolimatta luotettavuuden parantamiseksi pyysin aina tutkimuksen ulkopuolisen henkilön mielipidettä, kun tulkinnoissa oli epäselvyyksiä. Esimerkiksi, miten määritellään kuviokielen virke; mihin semioottiseen resurssiin nallen kuva (ks. kuvaa 3 ), jossa on $\mathbf{3} €$-hintalappu, luokitellaan, kuviokieleen vai sekä kuviokieleen että symbolikieleen; luokitellaanko sanan lyhenteet, kuten $s$. (sivu) ja $v$ (vastaus) luonnolliseen vai symbolikieleen. Tällä tavalla varmistettiin yksimielistä luokittelua. On huomioitava myös, että tämän tutkimuksen tarkastelu on rajattu vain 1. luokan ja 4. luokan oppikirjoissa olevaan luonnollisten lukujen yhteen ja vähennyslaskuun. Jotta tutkimustuloksia voitaisiin yleistää, tulisi tarkastella myös muiden luokka-asteiden oppikirjoja sekä laajempia matemaattisia osa-alueita. Jatkotutkimuksia ajatellen voisi myös kiinnittää huomioita tarkemmin semioottisten resurssien intersemiotiikkaan, siis niiden vuorovaikutukseen ja toistensa välisiin suhteisiin. 


\section{Kiitokset}

Artikkelin tekemistä on ohjannut dosentti Lari Kotilainen Helsingin yliopistosta.

\section{Låhteet}

Alshwaikh, J. \& Morgan, C. (2013). Analysing the palestinian school mathematics textbooks: a multimodal (multisemiotic) perspective. Teoksessa C. Smith (toim.) Proceedings of the British society for research into learning mathematics, 33(2), 70-75. London: The British Society for Research into Learning Mathematics.

Halliday, M. A. K. \& Matthiessen, C. M. I. M. (2004). An introduction to functional grammar. London: Arnold.

Herbel-Eisenmann, B. \& Wagner, D. (2007). A framework for uncovering the way a textbook may position the mathematics learner. For the Learning of Mathematics, 27(2), 8-14.

van den Heuvel-Panhuizen M. \& Wijers M. (2005). Mathematics standards and curricula in the Netherlands. ZDM International Journal of Mathematics Education, 37(4), 287-307.

Jellis, R. M. (2008). Primary children's interpretation and use of illustrations in school mathematics textbooks and non-routine problems: a school-based investigation. Doctoral thesis. Durham University.

Jewitt, C. (2014). Multimodal approaches. Teoksessa S. Norris \& C. D. Maier (toim.) Interactions, images and texts: a reader in multimodality (s. 127-136). Boston: Walter de Gruyter.

Jewitt, C., Bezemer, J. J., \& O'Halloran, K. L. (2016). Introducing Multimodality. London: Routledge.

Johansson, M. (2006). Teaching mathematics with textbooks: a classroom and curricular perspective. Doctoral thesis. Luleå University of Technology.

Joutsenlahti, J. \& Kulju, P. (2010). Kieliteoreettinen lähestymistapa koulumatematiikan sanallisiin tehtäviin ja niiden kielennettyihin ratkaisuihin. Teoksessa E. Ropo, H. Silfverberg \& T. Soini (toim.), Toisensa kohtaavat ainedidaktiikat (ss. 66-77). Tampere: Tampereen yliopistopaino.

Joutsenlahti, J. \& Vainionpää, J. (2010). Oppimateriaali matematiikan opetuksessa ja osaamisessa. Teoksessa E. K. Nieminen \& J. Metsämuuronen (toim.), Miten matemaatiikan taidot kehittyvät? Matematiikan oppimistulokset peruskoulun viidennen vuosiluokan jälkeen vuonna 2008 (ss. 137-148). Helsinki: Edita Prima.

Kautto, J. \& Peltoniemi, A. (2006). Selvää kärpännahkaa: Oppikirjan kuvituksen muutos ja käyttö opetuksessa (Pro gradu -tutkielma). Saatavissa

http://tampub.uta.fi/bitstream/handle/10024/93758/gradu01239.pdf?sequence=1\&isAllo wed $=y$

Kulju, P. \& Joutsenlahti, J. (2010). Mitä annettavaa äidinkielellä ja matematiikalla oppiaineina voisi olla toisilleen? Teoksessa E. Ropo, H. Silfverberg \& T. Soini (toim.), Toisensa kohtaavat ainedidaktiikat (ss. 163-178). Tampere: Tampereen yliopistopaino.

Lemke, J. L. (2003). Mathematics in the middle: measure, picture, gesture, sign, and word. Teoksessa M. Anderson, A. Sáenz-Ludlow, S. Zellweger, \& V. V. Cifarelli (toim.), Educational perspectives on mathematics as semiosis: From thinking to interpreting to knowing (ss. 215-234). New York: Legas.

Meaney, T. (2005). Mathematics as Text. Teoksessa A. Chronaki \& I. M. Christiansen (toim.) Challenging perspectives on mathematics classroom Communication (ss. 109-144). Charlotte NC: Information Age. 
Morgan, C. (2001). The place of pupil writing in learning, teaching and assessing mathematics. Teoksessa P. Gates (toim.), Issues in mathematics teaching (ss. 232-244). London: Routledge Falmer.

Morgan, C. (2006). What does social semiotics have to offer mathematics education research? Educational Studies in Mathematics, 61(1/2), 219-245.

Niemi, E. K. (2008). Matematiikan oppimistulosten kansallinen arviointi 6. vuosiluokalla vuonna 2007. Helsinki: Yliopistopaino.

Nugroho, A.D. (2010). Mathematics textbooks of primary 1 used in Singapore: a multimodal analysis of its intersemiosis. K@ta, 12(1), 72-91.

O’Halloran, K. L. (2005). Mathematical Discourse: Language, Symbolism and Visual Images. London: Continuum.

O’Halloran, K. L. (2009). Systemic functional multimodal discourse analysis (SF-MDA) approach to mathematics, grammar and literacy. Teoksessa A. McCabe, M. O'Donnell \& R. Whittaker (toim.), Advances in language and education (ss. 77-102). New York: Bloomsbury.

O'Halloran, K. L. (2015a). The language of learning mathematics: a multimodal perspective. The Journal of Mathematical Behaviour, 40, 63-74.

O’Halloran, K. L. (2015b). Mathematics as multimodal semiosis. Teoksessa E. Davis \& P.J. Davis (toim.), Mathematics, substance and surmise (ss. 287-303). Switzerland: Springer. doi 10.1007/978-3-319-21473-3_14

Ollikainen, T. \& Rossi, J. (2007). Puuduttavia rutiineja vai oivaltavaa oppimista? Analyysi perusopetuksen kolmannen luokan matematiikan oppikirjoista (Pro gradu -tutkielma). Saatavissa

http://tampub.uta.fi/bitstream/handle/10024/94256/gradu01601.pdf?sequence=1\&isAllo wed $=y$

Opetushallitus. (2015). Perusopetuksen opetussuunnitelman perusteet 2014. Tampere: Suomen yliopistopaino.

Schleppegrell, M. J. (2010). Language in mathematics teaching and learning: a research review. Teoksessa J. N. Moschkovich (toim.), Language and Mathematics Education (ss. 73-112). Charlotte, NC: IAP-Information Age.

Shore, S. (2012). Systeemis-funktionaalinen teoria tekstin tutkimisessa. Teoksessa V. Heikkinen, E. Voutilainen, P. Lauerma, U. Tiililä \& M. Lounela (toim.), Genreanalyysi tekstilajitutkimuksen käsikirja (ss. 158-185). Helsinki: Gaudeamus.

Tuomi, J., \& Sarajärvi, A. (2018). Laadullinen tutkimus ja sisällönanalyysi. Helsinki: Tammi.

Vilkuna, M. (toim.) (2008). § 864 Lause ja virke tekstin, lausuma puheen yksikkönä. Ison suomen kieliopin verkkoversio. Helsinki: Kotimaisten kielten keskus.

http://scripta.kotus.fi/visk/sisallys.php?p=864

\section{Tutkimusaineistot}

Forsback, M., Kalliola, A., Tikkanen, A., \& Waneus M.L. (2014). Tuhattaituri 1a. Helsinki: Otava. Hartikainen, S., Hurmerinta, E., Häggblom, L., Sipilä, A.R., \& Väistö, M. (2017). Yykaakoo $1 a$. Helsinki: Edukustannus.

Hartikainen, S., Häggblom, L., Nouiainen, P., \& Silvander, Y. (2017). Neeviikuu 4a. Helsinki: Edukustannus.

Kiviluoma, P. Nyrhinen, K., Perälä, P., Rokka, P., Salminen, M., \& Tapiainen, T. (2015). Tuhattaituri 4a. Helsinki: Otava. 
Rinne, S., Sintonen, A.M., Uus-Leponiemi, T., \& Uus-Leponiemi, M. (2016). Kymppi 1 Syksy. Helsinki: Sanoma Pro.

Rinne, S., Sintonen, A.M., Uus-Leponiemi, T., \& Uus-Leponiemi, M. (2017). Kymppi 4 Syksy. Helsinki: Sanoma Pro. 